\title{
Korero Pukapuka, Talking Books: \\ Reading in Reo Māori in the Long Nineteenth Century
}

By

Frith Te Aroha Driver-Burgess

\begin{abstract}
A thesis
Submitted to the Victoria University of Wellington in fulfilment of the requirements for the degree of Master of Arts

In History
\end{abstract}

Victoria University of Wellington 


\section{Abstract}

The introduction of reading to New Zealand by missionaries in 1815 was a catalyst for enormous change in how Māori communicated and recorded information. Reading was quickly adopted by Māori, who learned in mission schools initially, and increasingly taught each other, both in formal educational contexts and informally in village settings across the country. Missionaries were concerned to promote reading as a means of communicating the Christian gospel, and much of the early material available to Māori readers in reo Māori was ecclesiastical or scriptural works. However, in 1842 the colonial government established the first reo Māori newspaper, the first of around forty titles which were produced over the period $1842-1932$ by government, church and philanthropist, and Māori groups. Alongside news, speeches and other items, the niupepa included a wide range of texts that broadened the genres available in reo significantly. Many reports exist of Māori reading and writing in to the niupepa. Māori reading was, however, often carried out in conjunction with traditions of Māori debate and oral communication, which proved to be pragmatic approaches to the reading context of Māori in nineteenth century New Zealand.

Government-controlled niupepa in particular used translated texts, both in niupepa and bound separately, as a means of disseminating information on a 'civilised' life and urging Māori to take up European behaviours. Other niupepa, however, in particular the Anglican-Māori Te Pipiwharauroa, He Kupu Whakamarama and Te Toa Takitini and the Kotahitanga niupepa Te Puke ki Hikurangi, promoted reading as a means by which Māori could inform themselves, entertain themselves, and connect with other cultures. Rather than being subsumed by Pākehā culture, these niupepa writers aimed to enrich their lives as Māori by incorporating elements of what they read in the paper. Translated texts, reo Māori versions of originals from other languages, were certainly part of this change, with readers reporting their reflections on the text and its application in their lives. Although responses were varied to reading, with many Māori both reading and lacking interest in reading at the end of the long 
nineteenth century, a well-developed reading culture in te reo existed in New Zealand, Although reading was not engaged in by the whole population, it was, in many cases, highly respected and a part of daily and official life. 


\section{Acknowledgments:}

\section{Ehara taku toa i te toa takitahi, engari he toa takitini}

This thesis was only made possible by the kind and generous support of many people; whatever is done well here is well-done because of your encouragement, and errors are all my own.

To my erudite and skilled supervisors Lydia Wevers and Arini Loader, for setting me on the right course, pulling me back onto it, and for much patient and insightful advice and guidance, many many thanks; Matthew Vink, for many hours of patient editing, food and drink, and almost literally holding my hand over the final leg, I really can't thank you enough; Carolyn Driver-Burgess - Mum to the rescue - for moving in and taking care of everything else so I could write, and to the rest of the family for sparing her, so many thanks. Alana Cruikshank, for the care package and cheerleading, bro, thank you; Camilla Chaplow, Tessa Macaulay, Cassandra Burton-Wood, Arden Driver-Burgess, and a couple of unknown benefactors for bringing me delicious food while I wrote; Flo Baggett for the help with forms and submission; to my flatmates, for your practical support; and family, for your long-distance manaaki; St Michael's whānau, particularly David Newton, for your kind encouragement while I struggled; and of course to the many people who offered me proofreading help, motivational cartoons and emotional support, it meant a lot. Lastly, thank you again to Lydia Wevers and the History of Colonial Reading Marsden Scholarship, which enabled me to work on this thesis. Ko koutou ngā toa takitini! 


\section{Table of Contents}

\section{Contents}

Korero Pukapuka, Talking Books:.

Reading in reo Māori in the Long Nineteenth Century

Abstract

Acknowledgments: iv

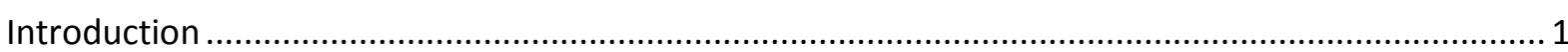

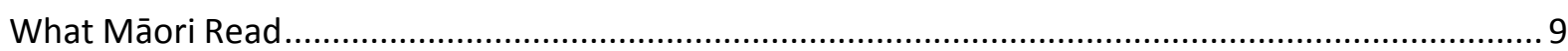

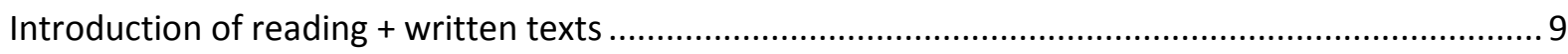

Texts available originally in reo Māori ................................................................................... 11

Commentary on range and patterns of texts translated into reo Māori........................................ 13

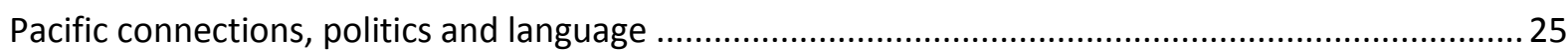

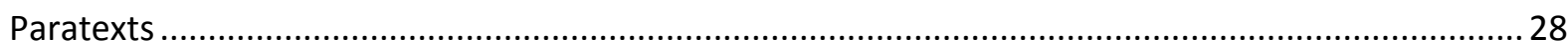

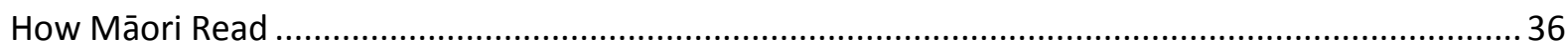

New Zealand Reading Practice .................................................................................... 36

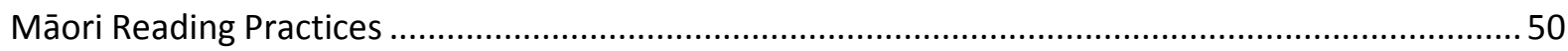

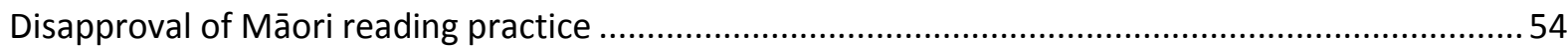

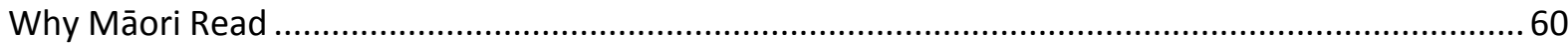

Literacy rates, entertainment and information ................................................................. 61

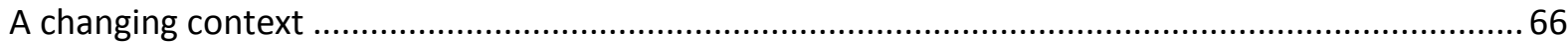

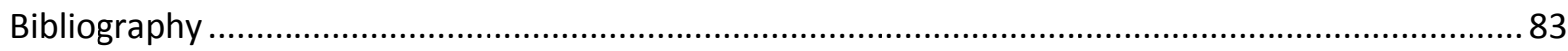




\section{Introduction}

In February 1928, an unnamed contributor wrote in to a reo Māori ${ }^{1}$ niupepa, ${ }^{2}$ Te Toa Takitini. His subject was the society he saw around him, and Māori lives within it. He wrote,

It is a new century. A new people, a new understanding, new practices, in this century. Look at us. 'The old things are of the past: they have been relinquished for new things.' ... The language of our children is Anglicised everywhere you go, and Māori are reading the niupepa, and English books. Every day, and every week, we hear of news of the world, and newspapers show us new treasures... The stagnant Māori ways are gone.

This anonymous writer, remarking on the beginning of the twentieth century, looks back on the nineteenth and surveys the changes he sees in Māori society. A great deal of new things, he explains, make up the world of 1928. Prominent in this writer's thinking is the English language, and the introduced skill of reading. Māori, he writes, commonly read the niupepa and books introduced during the last century, and through these broadening their knowledge, reading of current events and of far-off places. This observation foregrounds the changes which reading brought to Māori, and just a few of the ways in which Māori readers adopted reading skills, and put them to use in reading different kinds of texts. It also notes the influence of imported ideas and norms as catalysts of social change.

This thesis examines Māori reading, particularly of translated texts, during the long nineteenth century from the 1810 s to the 1920 s. This is the same period the unknown niupepa writer looks back at. Although excellent scholarship exists on Māori literacy, notably the work of C. J. Parr, Buddy Mikaere and

\footnotetext{
${ }^{1}$ Māori language

${ }^{2}$ newspaper
} 
Lyndsay Head, Lachy Paterson, and Shef Rogers ${ }^{3}$, and in New Zealand's reading culture, particularly Lydia Wevers and J. E. Traue ${ }^{4}$, very little looks specifically at Māori experience of reading in their own language. In order to shed some light upon this topic, this thesis draws heavily from the niupepa corpus, a collection of newspapers in reo Māori published online by the New Zealand Digital Library, and an underutilised treasure trove of Māori writing and writing in Māori spanning almost 100 years. The niupepa contain a wide variety of writing; reports, news both local and international, advertisements, and, most pertinently, both translations of European texts and literature, and editors', writers', and readers' reactions to reading such things. These sources have been searched, with particular attention to the very early niupepa and the niupepa around the end of the nineteenth century, for translated texts, which form the basis of my research. This main source is supplemented by other primary sources, including printed and bound translated books in reo Māori, and first-hand accounts from travellers, missionaries and commentators on Māori reading from the time. Scholarship on Māori texts, Māori printing, New Zealand's reading culture, and international reading culture have enabled the analysis of this primary data. Of course, a great deal of reading occurs with little to no record, readers passing over the page with hardly a trace of their presence. The primary and secondary sources I have used offer, however, a glimpse into reading culture as it was engaged in and discussed by readers. I have attempted to explain something of how Māori engaged with these texts, and the extent to which this engagement can be analysed.

\footnotetext{
${ }^{3}$ C. J. Parr, C. J., 'A Missionary Library: Printed Attempts to Instruct the Māori', in JPS, Vol.4, no.70, 1961, pp. 429-450, and 'Maori Literacy 1843-1867', in JPS vol. 72 no.3, Sept 1963, pp. 211234, Lyndsay Head and Buddy Mikaere, 'Was $19^{\text {th }}$ century Maori Society Literate?', Archifacts, Conference Papers, Vol.2, 1988, pp.17-20, Colonial Discourses: Niupepa Māori 1855-1863 (Dunedin: Otago University Press, 2006), 'Print Culture and the Collective Māori Consciousness', in JNZL, Vol. 28, issue 2, Nov. 2010, pp. 105-117,

'The Kohimārama Conference of 1860: A Contextual Reading', Journal of New Zealand Studies, No.12, 2001, pp.29-46, and Shef Rogers, 'Crusoe among the Māori: translation and Colonial Acculturation in Victorian New Zealand', in Book History, Vol 1, 1998, pp. 182-195.

${ }^{4}$ Lydia Wevers, Reading on the Farm: Victorian Fiction and the Colonial World (Wellington: Victoria University Press, 2010), J. E. Traue, 'Reading as a 'Necessity of Life' on the Tuapeka goldfields in Nineteenth-century New Zealand', in Library History, Vol.23, 2007, pp.41-48, and 'The Public Library Explosion in Colonial New Zealand', Libraries \& the Cultural Record, Vol.42, No.2, 2007, pp.151-164.
} 
During this period of nearly a century, Māori, already possessed of a rich and variable oral culture, took up the opportunity of learning to read with the advent of missionaries to New Zealand in 1814. A very few Māori pupils had learned to read and write in English at mission schools in Sydney and England at the very beginning of the nineteenth century. ${ }^{5}$ This was an important step in early literacy among Māori populations, and also indicative of missionary motivations in helping Māori learn to read: to teach Māori and enable them to teach others about Christian scriptures and beliefs. Christianity and Māori uptake of its scriptures was an important influence on the early development of Māori literacy, and in the earlier materials available to Māori. However, this thesis examines the development of Māori reading particularly in reo Māori, and therefore does not closely examine these early cases. Missionaries and Māori from the Bay of Islands soon developed a written form of reo Māori, with the first book in reo Māori, a grammar, printed in 1815. Māori took up reading and writing in such great numbers that missionary accounts abounded of Māori teaching each other to read, not only within 'monitorial systems' in missionarysponsored schoolhouses, but informally and across iwi boundaries as well. Bradford Haami recounts accounts of travellers through New Zealand in these early days encountering multiple signs, written on leaves, trees, bark, or sand, scattered on the landscape around New Zealand ${ }^{6}$. John White, similarly, writes that he met literate Māori readers throughout the North Island in the 1820s, eager for new reading material and particularly eager to swap tales with White, trading him their iwi stories in exchange for Jack and the Beanstalk and Romeo and Juliet ${ }^{7}$. This strongly suggests that not only were many Māori developing a robust and wide-spread reading culture, but that many were interested in stories from the corpora of other cultures. It is these translated texts, windows into other cultures, that form the subject of this thesis.

\footnotetext{
${ }^{5}$ Bradford Haami, 'Tā te Āo Māori' in Danny Keenan, ed., Huia Histories of Māori (Wellington: Huia 2012), p.168.

${ }^{6}$ Haami, 'Tā Te Āo Māori', p.172.

7 John White in Johannes Andersen, 'Māori Printers and Translators', in The history of printing in New Zealand, ed. Richard Alexander McKay (Wellington: Club of Printing House Craftsmen, 1940), p.35.
} 
Missionary and later government translators printed a handful of stories translated from English sources from the 1840s onwards. Many previous examinations of Māori printing or literacy focus comment on these texts, which skewed heavily towards religious material. The Bibliography of Printed Māori to $1900^{8}$ written by William Williams and the more heavily annotated later Books in Māori Index ${ }^{9}$ both list, among bills, petitions to the government and advertisements, a number of stories translated from English. These were largely moral fables and retellings of 'Christian death-bed scenes'10; the deaths of deserving Christians. However, when niupepa began to be printed in 1842, a wide range of translated texts were included within their pages. These texts have largely escaped notice in studies of Māori texts. The vast majority of the texts included in the niupepa were not anthologised in any other printed form, although some appeared in schoolbooks or more than one niupepa, and a few were excerpted from the few books in reo Māori. This unfortunately effectively hid them from view and excluded them from much examination. Lachy Paterson, in his very useful study of the niupepa, Colonial Discourses, examines niupepa content, and remarks on the paucity of previous scholarship on their contents. ${ }^{11}$ Paterson, however, does not focus in any great depth on the translated texts within the niupepa.

The first chapter of this thesis examines what, in fact, Māori did read during the half-century 1842-1928, from the first translated books in reo Māori to the demise of the niupepa in the early twentieth century. It briefly surveys the introduction of print literacy to Māori, first in English, and then in reo Māori, and discusses the prevalence of texts translated into reo Māori, and their reception by readers, as compared to the wider corpus of texts available in reo Māori. The aforementioned religious fables are examined, particularly the four short stories,

\footnotetext{
${ }^{8}$ Herbert W. Williams, A Bibliography of Printed Māori to 1900 (Wellington: Government Printer, 1924).

${ }^{9}$ Penny Griffith and Phil Parkinson (compilers), Books in Māori 1815-1900/ Ngā Tānga reo Māori: An Annotated Bibliography/ Ngā Kohikohinga Me Ōna Whakamārama (Auckland: Reed Publishing, 2004).

${ }^{10}$ H. W. Williams, p.x.

11 Lachy Paterson, Colonial Discourses: Niupepa Māori 1855-1863 (Dunedin: University of Otago Press, 2006), p.16.
} 
originally written for children, translated for reo Māori readers in the 1840s, and argues that the stories and the short didactic dialogues published with them set up a narrative of missionaries as benevolent teachers and Māori as untutored children. This argument is followed by a brief survey of religious materials in translation throughout the rest of the long nineteenth century. The brief era of government-sponsored novel translation is then examined, as are the 1850s translations of British novels Robinson Crusoe and Pilgrim's Progress. This section argues that the selection of these novels, their presentation to readers, and Māori readers' reported reactions to the texts, indicate government aims to 'civilise' Māori readers through exposing them to exemplars in translated literature. Later texts such as Felicia Hemans' The Hour of Prayer and various pieces of travel writing, including unflattering depictions of 'Islanders' seem to develop this theme, seeking only to socialise Māori through translated texts into European ideas; the only future that some government officials saw for Māori as a culture. ${ }^{12}$ Even those texts which were not explicitly promoting civilisation sought to promote moral messages, most clearly illustrated by the number of animal fables published in niupepa in the $1850 \mathrm{~s},{ }^{13}$ and in advice to mother and wives ${ }^{14}$ translated from an English book and printed in Māori-operated niupepa ${ }^{15}$ of the early nineteenth century. This range illustrates the enduring popularity of translated texts as a medium for communicating morals and behaviour to readers.

The second half of this chapter covers unexpected texts that do not appear to have been discussed in scholarship as yet. This second half examines two sets of articles published in two different niupepa during this time period; letters from Queen Pomare IV of Tahiti, translated into reo Māori, and songs and Hawaiian legends, which are examined next to reo Māori and Māori legend

\footnotetext{
12 Henry Tacy Kemp, He pukapuka ako tenei i nga ritenga pai e-maha o roto o te taonga nei o te moni, i nga tikanga pai hoki, o te hokohoko, o te aha, o te aha (Wellington: Independent Office, 1852).

${ }^{13}$ Particularly in The Māori Messenger.

14 'He Kupu ki nga Whaea: Te whaea raua ko Tana Tamariki', in Te Pipiwharauroa, No.88, July 1905, pp.2-3. Translation of original by Mrs. C Northcote, also see Te Pipi No.91.

${ }^{15}$ All references to Māori language niupepa are to the digitised versions available at the NZDL Niupepa Māori website: http://www.nzdl.org/cgi-bin/library.cgi?a=p\&p=about\&c=niupepa.
} 
equivalents in the Anglican niupepa Te Pipiwharauroa. This section argues that British colonial attitudes were not the only ones presented to reo Māori readers, nor was such a presentation the only agenda of the niupepa and other publications. On the contrary, the inclusion of these two narratives from neighbouring pacific and indigenous societies nods to the connectivity of colonial and pacific societies of the era, and to the links maintained between indigenous societies.

Lastly, the first chapter examines the presence of paratexts, associated texts such as titles, introductions, and editorials, which accompany many texts published in reo Māori. Understanding these offers another angle toward understanding the intent of the publishers of the various texts, and points the reader towards specific interpretations or focuses as they read the text. This section argues that paratexts were used to influence the reader in ways that were not wholly borne out by the texts themselves, and also to expand upon those texts.

The second chapter covers the more vexed question of how Māori read. The evidence for this chapter is drawn from three main sources: firstly studies of reading practice in the wider geographical and social context of the time; secondly, accounts from first-hand observers of Māori reading; and thirdly, primary sources from niupepa and pamphlets of the time which either instruct Māori how to read, or shed light on the environment of reading at the time. Firstly, the chapter examines how, and what, Pākehā New Zealanders were reading during the second half of the nineteenth century, using J. E. Traue's research ${ }^{16}$ on libraries as a main source. It then discusses Sir Robert Stout's 1908 treatise $\mathrm{e}^{17}$ on how New Zealanders should be reading, and argues that New Zealand's reading culture was fairly democratic, with fiction and 'low-brow' books popular, but that some commentators were nevertheless highly prescriptive. This, I argue, formed the context for Māori reading. This chapter

\footnotetext{
${ }^{16} \mathrm{~J}$. E. Traue, 'Reading as a 'Necessity of Life' on the Tuapeka goldfields in Nineteenth-century New Zealand', in Library History, Vol.23, 2007, pp.41-48, and 'The Public Library Explosion in Colonial New Zealand', Libraries \& the Cultural Record, Vol.42, No.2, 2007, pp.151-164.

${ }^{17}$ Stout, Sir Robert, How and what to Read (Auckland: Book Exchange, 1908).
} 
also discusses the availability of reading material in reo Māori, and surmises that, while well-to-do Māori collected books in much the same manner as well-to-do Pākehā, most Māori readers were more likely to have access to niupepa than to bound books, which were expensive and printed in relatively small runs. Despite the niupepa, I also argue that the paucity of texts in reo Māori constrained reading in reo Māori. Niupepa themselves, however, and their flourishing comment and letters sections, are testament to the existence of their readers.

In the second part of the second chapter, I argue that it is quite clear that Māori reading practice differed from prescribed 'civilised' reading, in that it was often aloud, communal, and integrated into oral debates about its content. Reports abound on the prevalence of such reading, and are often disapproving of it. However, I also argue, drawing from Benedict Anderson's 'Imagined Communities' $^{18}$ theory and Lachy Paterson ${ }^{19}$, that reading brought Māori communities together, and created both a stronger nation-wide community through the explicit intentions of the niupepa, but also gave readers a forum for sharing ideas with a 'community' in far-flung parts of the country. Lastly, I sketch how Māori reading developed in parallel with a wider reading culture in New Zealand, and how changes in the fortunes of many Māori affected enthusiasm for, and debates around, reading.

The third and final chapter focusses on examining some of the differing reasons Māori readers chose to read. The chapter opens by discussing the view, not uncommon by the end of the nineteenth century, that reading was a waste of time and a tool by which Pākehā institutions controlled Māori children. It examines articles in Te Pipiwharauroa lamenting children's lack of interest in reading, and Bradford Haami's memories of grandparents burning their mokopuna's schoolbooks. Niupepa, now published by Māori, however, presented a case for reading, particularly reading the pieces contained within their pages, and informing themselves as a means of self-determination. Mikaere and Head's article on Māori literacy is used to support this idea of Māori

\footnotetext{
18 Benedict Anderson, Imagined Communities (New York: Verso, 1983).

${ }^{19}$ Lachy Paterson, Colonial Discourses (Dunedin, University of Otago Press, 2006).
} 
utilising reading because it was practically useful as a tool for recording and communicating ideas. The chapter surveys reasons presented to Māori readers for reading by the government in the mid-century, and the complementary goals presented of both entertaining and informing readers. Both, this chapter argues, were used by the government as controlling mechanisms and part of a programme of assimilation into Pākehā norms. At the same time, others, notably Apirana Ngata and Reweti Kohere, urged that Māori readers should preserve and nurture literacy as a means of gaining power and self-determination, through access to the knowledge contained in print sources. These same people wrote about their own responses to translated texts, and the potential for other readers, too, to enjoy the texts as literary pieces of merit, and as fodder for considering their own lives and actions. Similarly, readers are urged to consider reading about other cultures as a way of locating their own culture in relation to others, for example the Hawaiian legends and songs presented in $\mathrm{Te}$ Pipiwharauroa. This chapter argues that while opinion was divided among Māori as to whether reading was worth its pitfalls, this was largely a result of Englishmedium education edging out reo Māori literacy, and a number of Māori readers both took pleasure in reading, and encouraged it in others. Reading in reo Māori was contested at the end of the century, but still extant, and engaged in for as many reasons as there were readers. However, it was very much shaped by the wider social context. 


\section{What Māori Read}

The arrival of reading in Aotearoa is a story of rapid change, rapid adoption of new practices by Māori, and rapid synthesis of written and new practice, of new texts and old stories, to suit the needs of daily communication. Some material was written in New Zealand for original publication in reo Māori, and this originally reo Māori material most likely outnumbered translated texts from the beginning, and grew to dwarf translated texts by the close of the nineteenth century. However, other reading material was provided by texts translated from English and other languages, and published in the form of bound books, pamphlets, or within reo Māori language press, the niupepa. As the base material on which a reading culture was built, the history and range of texts available to nineteenth century readers of reo Māori gives invaluable context to the literary world of reo Māori readers.

\section{Introduction of reading + written texts}

Before the arrival of Europeans in Aotearoa, Māori manuscripts and reading of print did not exist. However, written or drawn symbols were common, in carvings and weaving depicting or symbolising events or people, and in moko tattooed on faces and bodies with specialised meanings. Bradford Haami ${ }^{20}$ also cites Kai Tahu cave drawings and, in particular, pictograms, said to have been originated with navigators from Hawaiki, with specific, set meanings, such as 'come here' 'go back' or 'gather for war'. Alphabetic symbols with a standard word or concept attached to them, however, were not in common use, and therefore no 'reading' of a written language took place. Literacy in the form of a highly-developed oral culture and wide-ranging mythological, genealogical, and historical corpus of oral literature, however, thrived. A practice of debate and oratory was, of course, central to transmitting and engaging with this corpus, and the marae ātea was a central, public space where such debate often took place. When European missionaries arrived in New Zealand in 1814, printing, writing and reading arrived with them. Missionaries considered the acquisition

\footnotetext{
${ }^{20}$ Bradford Haami, Pūtea Whakairo: Māori and the Written Word (Wellington: Huia Publishers, 2004), p.17.
} 
of literacy skills and the provision of books in the native language crucial to their role in purveying both holy scriptures and civilisation, and set out quickly to create a written form of reo Māori, and to work with local Māori willing to learn this new tool.

Māori, in general, responded by taking up reading with great enthusiasm, with many literate Māori acting as teachers to others. Missionaries staffed village schools with newly-literate Māori ${ }^{21}$, and Māori teaching one another was very common, either informally, or through deliberate missionary policy; Kendall, for instance, 'employed the 'monitorial system', in which children taught others through repetition, so as to hasten the spread of literacy'. ${ }^{22}$ Anecdotal accounts of this abound in missionary reports. ${ }^{23}$ While these reports may have been coloured by missionaries' interest in being able to witness and report the success of their efforts, they are numerous and, unless we suspect reports of being falsified entirely, certainly point to a considerable uptake of literacy. These records are also supported by other accounts, such as John White's, ${ }^{24}$ of Māori spreading literacy as both a form of recreation, and a religious observance. ${ }^{25}$ The latter motivation, that of becoming closer to the god preached by the missionaries through reading scriptures presented as this god's own communication to humans, was reported to be widespread. ${ }^{26}$ This is in large part attributable to the fact that a great many early texts printed in Māori were

\footnotetext{
${ }^{21}$ Lachy Paterson, Colonial Discourses: Niupepa Māori 1855-1863 (Dunedin: Otago University Press, 2006), p.40.

${ }^{22}$ Bradford Haami, 'Tā te Āo Māori', in Huia Histories of Māori: Ngā Tāhuhu Kōrero (Wellington: Huia Publishers, 2012).

${ }^{23}$ D. F. McKenzie cites several early accounts, in Oral Culture, Literacy \& Print in early New Zealand: the Treaty of Waitangi, (Wellington: Victoria University press: 1985), pp. 14-17.

${ }^{24}$ John White in Johannes Andersen, 'Māori Printers and Translators', in The history of printing in New Zealand, ed. Richard Alexander McKay (Wellington: Club of Printing House Craftsmen, 1940), p.35, and Lydia Wevers, 'Fiction - Romance, Māori and pioneer fiction, 1880s to 1910s', Te Ara the Encyclopedia of New Zealand, updated 14-Oct-14. URL:

http://www.TeAra.govt.nz/en/fiction/page-2.

${ }^{25}$ Bradford Haami, Putea Whakairo: Māori and the Written Word (Wellington: Huia Publishers, 2004), p.19.

${ }^{26}$ The original translations of the Bible into reo Māori were sometimes presumed to be the literal word of God, and this air of the sacred extended to the words used, to the extent that the retranslation of the Bible in 1887 met with marked disapproval, as detailed in Peter Lineham, 'Tampering with the Sacred Text: The Second Edition of the Māori Bible' in A Book in the Hand (Wellington: Auckland University Press, 2000), p.40. Bradford Haami, Putea Whakairo: Māori and the Written Word (Wellington: Huia Publishers, 2004), p.20 cites more reactions to the Paipera.
} 
either ecclesiastical, or written or translated primarily to aid the understanding and observance of Christian tradition. This is unsurprising, as much early printing was carried out by missionaries. However, as the number of printers in New Zealand multiplied with more widespread European settlement, and groups producing reading material diversified, the range of texts available in Māori also diversified to some extent, to include practical instruction and non-fiction works, poetry, letters and, importantly, many translations from other languages, in addition to other religious and ecclesiastical texts.

Although in the mid-Nineteenth century a small minority of Māori (which grew as the century went on) could read in English, it's likely that most Māori read primarily in reo Mãori. This was the first language in which literacy was taught and spread around the country; it was the language of daily use for Māori and non-Māori alike in the mid-century, and remained so for Māori into the beginning of the Twentieth Century, even after the introduction of education in the English language. These readers, like many others around an increasingly connected globe, were often engaged both in their communities and looking outwards into the affairs and culture of the wider islands and world, including a great deal of Pākehā culture. A look at the variety of texts translated into reo Māori from other languages, and their various features and receptions, allows a glimpse into this aspect of Māori literary history, and how it expanded to include and adapt elements from foreign literary corpora, strange stories and new ideas. Māori were far from passive recipient of new texts, and the changes applied to translated texts are indicative of how Māori readers appropriated and made use of reading new material.

\section{Texts available originally in reo Māori}

Translated texts, that is, texts from other cultures written in other languages and translated into reo Māori either within Aotearoa or offshore, were by no means the majority of texts available to readers of reo Māori. Most texts were, in fact, composed in New Zealand for the consumption of a reo Māori-reading audience. A prominent example of this might be reo Māori text of the Treaty of Waitangi. Released in reo Māori (discounting, for the purposes of 
example, the accompanying English text), it was nonetheless composed and written by in English by English-speakers, then translated into reo Māori. Given the difficulty for even bilingual scholars to mentally compose a text in their second language, even texts written down for the first time in reo Māori, but composed by English-speakers, could be seen as translated texts. These texts may thereby carry an element of the composition and expression of the language they were originally expressed in. It is impossible to identify every text, published in reo Māori, which was composed in English or by a native Englishspeaker, but the majority of printers, until the Māori-controlled niupepa became a presence in printing, were Pākehā and spoke English as a first language. For readers, then, the translated texts available for them to read were, from the start, an adaption of English composition and print culture to suit Māori reading context, and the nuance of Māori vocabulary and expression.

A great deal of ecclesiastical literature was translated into reo Māori from English and Latin, beginning with the first translations into reo Māori. An argument could well be made for examining these texts, as they made up a large proportion of the texts available to early Māori readers, and were certainly widely distributed and read. However, the majority of these texts were of a very similar nature. Catechisms, gospel translations and other biblical texts (followed by complete Biblical texts), and hymns were widely published, but tell us little about Māori engagement with and adaptation of texts, as they closely followed forms, language patterns and specific content designed for the context of (in the main) the Anglican, Catholic and Wesleyan churches. These texts were, in essence, utilitarian; they were necessary tools for the practice of Christianity in reo Māori. As such, they were largely read as sourcebooks - a guide to ritual, for instance, in the Anglican prayer-books, or a list of English hymns in the hymn books which were soon printed, or printed catechisms. Although this thesis touches on these religious texts, they have in general been well-canvassed, particularly the history of the Paipera Tapu, the Bible in reo Māori. Subsidiary religious texts, for example the hymns translated or composed to English tunes in the niupepa, or the many moral fables with explicit references to Christianity, 
are less well-known, and will be briefly examined in an upcoming section. In many cases however, more interesting inferences can be drawn about the other texts of literary or cultural, rather than primarily religious texts, which appear to have been published with little metadata. Likewise, the focus of this thesis is on works translated from other languages into reo Māori, and how reo Māori readers translated, accepted, integrated or adapted these texts to better suit their needs and wishes for reading material.

\section{Commentary on range and patterns of texts translated into reo Māori}

The range of texts translated into reo Māori was, of course, decided by the translators, printers, and publishers who produced translated texts for reo Māori readers. In the early days of Māori reading, books and other materials were overwhelmingly produced by the missions. Herbert W. Williams, himself a bibliographer of Māori materials and grandson of the missionary William Williams, states in 1924 that "during the first thirty years the Missions - Anglican, Wesleyan, and Roman - were responsible for almost the whole of the output."27 After this, the settler government became a prolific producer of translated texts, but Williams estimates that "not less than $45 \%$ of the items recorded [in his Bibliography] were from the presses of the Anglican mission"28. Williams also notes the growing output from the settler government, stating that "it was necessary, even from the earliest days, that many Government papers, such as proclamations, Gazette notices, and Acts of parliament, should be translated into Maori; but in addition to this the government... has shown its interest in the Maori population by bringing out, from time to time, translations of various improving works" 29 These improving works provide an intriguing case study in what was considered by the government and the mission presses appropriate reading material for Māori. Another indicator of Māori action around translated texts is in the various niupepa in operation from 1842, including Māori-operated niupepa - first Te Hokioi in the 1850s, and a small cluster at the end of the

\footnotetext{
${ }^{27}$ Herbert W. Williams, A Bibliography of Printed Māori to 1900 (Wellington: Government Printer, 1924), p.vii.

${ }^{28}$ Williams, p.vii.

${ }^{29}$ Williams, p.vii.
} 
century in the 1890s. Through these, iwi and pan-Māori movements such as the Kingitanga, Kotahitanga, Te Aute College Students' Association, and the Anglican Diocese of Waiapu were able to present translated content with their own commentary and presentational angle, and did so. Many of these texts, in particular, were accompanied by paratexts - material outside the text but connected with it. ${ }^{30}$ These ranged from introductions and author or translator's notes in bound volumes, preambles attached to bills, and editorial comments, accompanying articles, or even notes as to source, title and context, around a text. Niupepa in particular provided a perfect vehicle for views in response to translated texts.

The range of texts translated into reo Māori shows some homogeneity, but also a surprising amount of variation. The most striking pattern discernible in the range of translated texts is the change over time of their range. Initially, translated texts skewed heavily towards religious subjects. In the 1850 s came a brief experiment with novel translations for the sake of acculturation. After the 1850s, more texts translated from news items and general 'snippets' became used in wider currency, and from the 1880 s onwards, poetry and literary extracts became popular within the magazines.

In terms of separate bound volumes, the majority of translated books available to reo Māori readers were indeed religiously inflected. Hymn books, catechisms and prayer books have been briefly discussed above. However, a devotionally-motivated set of further materials was available to reo Māori readers from the 1840 s onwards: moral parables, prayers and scriptural fables. Three moral fables for children were translated and published by missionaries in the early 1840s; Agathos, The Rocky Island, and The Little Wanderers, published as "Agathos: Ko te ritenga o te ingoa nei, ko te tangata pai [The meaning of the name is, a good man]", "Te Motu Kohatu", and "Ko Nga Tamariki Haereere Noa" respectively . A third allegory from the same author, The Tent on the Plain, was published as "Te Teneti e Tu Ana i te Mania" in 1851. All four texts were

\footnotetext{
${ }^{30}$ H. Porter Abbot, The Cambridge Introduction to Narrative (Cambridge: Cambridge: 2008), p.239.
} 
translated by missionaries, and printed on the mission press at Te Waimate. The first, Agathos, published in 1843, was translated by James Davis and Thomas Williams. Te Motu Kohatu and Ko Nga Tamariki Haereere Noa, however, are all attributed to Elizabeth Colenso for translation into what the Books in Māori Index identify as the Waikato dialect. All four, likewise, were translated from a pair of volumes of allegories and "Sunday stories" written for children by the noted orator and Church of England bishop, Samuel Wilberforce. ${ }^{31}$ Wilberforce states in his prologue to the volume that it had been written to fill a gap for parents, caused by a lack of devotional stories suitable to be read to Children on the set-aside day of Sunday, in order that children not learn to associate the day entirely with boredom, but instead be led through a gentle allegory towards devotional thoughts worthy of the solemn occasion.

The book contains ten allegorical stories, each with children as the main characters, and teaching a lesson about Christian devotion and behaviour. Each is, likewise, followed by a set of suggested questions and answers from parent to child, to draw out the parallels between allegory and Bible. The four translated texts, separately published in coarse brown paper covers, ${ }^{32}$ all included this short question-and-answer dialogue. The original English-language stories and their following question-and-answer narratives were written for children, and the introduction to each story specifically states that they are to be used as a guide for the "FATHER" and the "CHILD" to negotiate the symbolism of the stories. However, although the latter three volumes of translated reo Māori children's stories follow this model, with the narrative set out for "matua [father]" and "tamaiti [child]", the first of the set to be published, Agathos, subverts this more explicitly towards the aims of its publishers, laying out the questions for the "Kaiwakaako [teacher]", and the answers for "Tangata Maori [Māori person]". Like many other texts, this adaptation of the original is clearly designed to suit the text better to its intended use - to a didactic situation in which the role of

\footnotetext{
${ }^{31}$ Samuel Wilberforce, Agathos and Other Sunday Stories (London: Seeley and Burnside, 1842), and The Rocky Island and other Parables (London: James Burns, 1840).

32 Copies in original binding can be viewed at the Alexander Turnbull Library. Physical particulars for each text are given in the Books in Māori Index.
} 
teacher is probably taken by a missionary ${ }^{33}$, and a Māori pupil. The narrative assumes that these roles are exclusive, with the Mãori person and the teacher mutually exclusive. Literate Māori, however, often cast themselves, or were cast by missionaries, ${ }^{34}$ in the role of teacher, spreading literacy from community to community. It is not known whether these early translated texts were used in such contexts, but it is very likely - and the use or otherwise of the Question and Answer, and negotiation of its implications, illustrate the probable gap between printers' intentions and readers' practice that many translated texts may point to.

Other translated texts available to reo Māori readers before 1850 were almost exclusively religious, and included The Story of Ann Chandler, a story of Christian religious devotion; an adapted Scriptural History; and The Pearl of Days, an English homily on the usefulness of a Sabbath to the 'working classes', here re-appropriated by translators to be presented to Māori readers in their own language, in a far-flung corner of the globe. Religious works became a smaller share of the materials available to reo Māori readers as the century progressed, but were ever-present, with homilies (such as The Two Lambs), hymns, scriptural histories and other materials produced throughout the century.

Publishing changed rapidly after the establishment of a settler government, however. The Missionaries' press at Waimate in Northland moved to St John's College in Auckland sometime around $1850^{35}$ and became less prolific, and the colonial government became a printer in its own right, with Governor George Grey commanding several translations ${ }^{36}$. These productions, among many texts in English, others aimed specifically at Māori and printed in reo Māori. Most interestingly, among reading material made available by the

\footnotetext{
${ }^{33}$ Although Māori reading teachers were certainly in existence at this time, the distinction between 'teacher' and 'Māori person' suggests that the translators' expectation, at least, was for the teacher to be non-Māori.

${ }^{34}$ Hakaraia Kiharoa, to take one example, was made Head Teacher at Otaki by the missionary Octavius Hadfield. See Otaki Maori Land Court Minutebook - 26 March 1874, accessible at URL: http://horowhenua.kete.net.nz/en/site/documents/1833-otaki-maori-land-court-minutebook26-march-1874.

35 Williams, Bibliography, p.vii.

${ }^{36}$ Shef Rogers, 'Crusoe Among the Māori: Translation and Colonial Acculturation in Colonial New Zealand', in Book History, Vol.1, No.2 (1998), p.6.
} 
government were two complete novel texts translated into reo Māori. The colonial government of the 1840 s and 1850 s sponsored a small number of translations into reo Māori by Henry Tacy Kemp. Known in reo Māori as Te Keepa, Kemp created three translations of British books, two of which were, furthermore, were complete early novels. The two novels translated were Robinson Crusoe by Daniel Defoe, and The Pilgrim's Progress, by John Bunyan. Both, moreover, could quite neatly be described as 'improving literature', and Shef Rogers suggests that they were part of an "explicit government policy of Māori acculturation"37. Lachy Paterson makes the point, however, that though such texts may with hindsight appear dull and rather preachy, they 'reflected the changes that many Māori were themselves trying to effect' ${ }^{38}$ In this they were also exemplary of many government and mission translations of the day. Both were attractive from a missionary and a paternal acculturation perspective. The details of their translation and presentation to Māori communities, moreover, belie more of the publishers' motivations. Robinson Crusoe, the first of the two, is a good representative example of the small number of long-form translated literary pieces. This novel was presented to Māori with the front-page information "He reo Māori / he korero tipuna Pakeha no mua, ko Ropitini Kuruho, tona ingoa [A Māori translation of a Tale of a historical Pākehā of time gone by, whose name is Robinson Crusoe]".

Defoe's classic early novel of shipwreck and exploration had been presented to its original English-language-literate audience in the form of a firstperson, personal account, explaining the voyages and misadventures of the titular Crusoe. It had moreover been based upon the well-known account of Alexander Selkirk, 'whose famous account of his trials and adventures on Juan Fernandez ${ }^{\prime 39}$ became the base material of Defoe's novel. Accepted despite this as a work of fiction in England, it was deeply ingrained in the literary imagination of the missionaries and settlers of the British Empire, including those in New

\footnotetext{
${ }^{37}$ Rogers, Crusoe among the Maori, p.182.

38 Paterson, p.35.

${ }^{39}$ Lydia Wevers, Country of Writing: Travel Writing and New Zealand 1809-1900 (Auckland: AUP, 2002), p.49.
} 
Zealand. William Colenso had Selkirk's story in mind as he retold his own explorations of the New Zealand landscape, ${ }^{40}$ and Crusoe was the subject of one of three children's puzzles on board the ship Charlotte Godley travelled to New Zealand on in $1850 .{ }^{41}$ The fictional tale of Robinson Crusoe became a cultural colossus, and a desire to acquaint Māori with such a significant character in the British imagination may have influenced Kemp's selection of this text for translation. When the book was translated into reo Māori, however, it was presented as a factual work, a historical account of a figure who actually existed in some past English era. Why this strange misrepresentation of the story occurred can only be grounds for speculation. Shef Rogers points out ${ }^{42}$ that the Kemp-Government translation of Crusoe immediately followed his translation of a non-fiction text, Easy Lessons on Money Matters, a work which "naturally stresses the workings of capitalism, a concept essential for the success of Grey's savings banks and for increasing the colony's trade" ${ }^{43}$ This work, however, proved very unpopular, with the author admitting later in life that it "died a natural death" 44 Robinson Crusoe, however, depicts a man "fascinated, even obsessed with the value of his own labour and the relative worth of specie" 45 . In other words, Crusoe was a fictional re-telling of a few of the capitalist principles that had proven so unpopular when presented in Easy Lessons in Money Matters. It is possible that Robinson Crusoe, being presented as a biographical account rather than a fictionalised one, was attempting subtly to make the story (and its behavioural and economic baggage) more appealing to its intended readers.

Bibliographers of Robinson Crusoe's adaptation into reo Māori certainly felt that a work in fiction or an allegory was less attractive to readers; William Swainson, an early Attorney-General and advocate for Māori legal interests ${ }^{46}$,

\footnotetext{
40 Wevers, Country of Writing, p.49.

${ }^{41}$ S. Rogers, p.190.

${ }^{42}$ S. Rogers, p.188.

${ }^{43}$ S. Rogers, p.187.

${ }^{44}$ Henry Tacy Kemp, Revised Narrative of Incidents \& Events in the Early Colonizing History of New Zealand, from 1840 to 1880 (Auckland: Wilson and Horton, 1901), p.11.

${ }^{45}$ S. Rogers, pp.187-188.

${ }^{46}$ Graeme Reid, 'Swainson, William', from the Dictionary of New Zealand Biography: Te Ara - the Encyclopedia of New Zealand, URL: http://www.teara.govt.nz/en/biographies/1s29/swainsonwilliam, accessed 18 March 2015.
} 
wrote in 1859 that "'Robinson Crusoe' has no charms for [Māori] because it is not true," ${ }^{47}$ a statement later repeated without editorial by the Books in Māori index. It is also curious to note, in light of the translator's so-called assumption that Māori would more readily accept an allegory than a factual treatise, that Robinson Crusoe was presented as a factual text. Thomas Hocken, in fact, states in 1900 that "as [Pilgrim's Progress and Robinson Crusoe] were exactly suited to native taste they were in high favour, until the inevitable Killjoy made it known that they were allegories, and then all interest ceased." ${ }^{48}$

It may be that Kemp and his government backers were mistaken in a belief that literate Māori would favour a fictional story, or more precisely an allegory (as such are both Pilgrim's Progress and Robinson Crusoe), and this mistake has been correctly identified by bibliographers over the years. However, Shef Rogers makes the excellent point that Māori were highly engaged with translated literature, including allegories contained within Biblical texts, as a literary form ${ }^{49}$. A culture with a highly developed oral tradition was, moreover, not unfamiliar with allegory. It is reasonable to suppose that Māori readers were eager for stories of true events from a newly expansive world, and greatly enjoyed reading true stories and the histories of European events and figures. However a fondness for fact does not preclude an understanding or enjoyment of fiction, nor did it appear to stand in the way of Māori reading what were clearly understood as allegories - including the four religious allegories previously discussed.

Despite the presentation of the text as a factual account, and despite the claims that Māori had a pronounced distaste for fictional texts, accounts also exist that contradict this. A Wellington newspaper reports that "translating... standard English works adopted to their peculiar tastes has been attempted with complete success; the book now before us [Robinson Crusoe] has been received

\footnotetext{
${ }^{47}$ William Swainson, New Zealand and its Colonisation (London, 1859), p.45.

${ }^{48}$ T. M. Hocken, 'Some Account of the beginnings of Literature in New Zealand: Part I, the Maori Section', TNZI, Vol.33, 1900, p.488.

${ }^{49}$ S. Rogers, p.191.
} 
by the natives with intense interest," ${ }^{50}$ and goes on to relate an anecdote in which a group of hospitalised Māori appear very eager to access the book, reading it aloud in a group over two successive days. It is also worth noting that the nervousness expressed over Crusoe's reception as a fictional or non-fictional text is, in the primary evidence, solely a Pākehā preoccupation. Māori commenting on the text make no mention of this as an issue. In an entertaining digression within the letters pages of Te Waka Māori o Niu Tirani in 1875, an Hon. Mr. Ngatata ${ }^{51}$ complains that while speeches of Māori members of the Legislative Council have been excluded from the newspaper's pages, "such tales as that of Robinson Crusoe and other trivial things" had sullied its pages instead, and accordingly "the name of that paper had better be altered to 'Robinson Crusoe'."52 The story of Crusoe had evidently made its way, twenty years after its translation, into the popular imagination of enough reo Māori readers for the disparaging reference to be understood. Perhaps it had indeed become the byword for a trivial tale it is here used as.

Reading the disparate pieces of information together, a picture appears, if slightly out-of-focus, of a new type of literature, available to the reo Māoriliterate population for the first time, exciting a good deal of speculation and interest among readers. Whether the eventual drop-off in popularity for the book and eventual disparagement of its contents, however, was due to the discovery by Māori readers that the book was a work of fiction is an appealing claim, but one that dismisses a range of other factors. Rogers, once again, points out that Robinson Crusoe is a fairly heavy-handed allegory, elevating the selfreliant adventurer and depicting Friday as little more than a caricature. Accustomed and acclimatised to the pervasiveness of the popular Robinson Crusoe in their own culture, missionary and colonial translators may have been led by their own assumptions of appropriate texts in choosing this novel for translation. Rousseau commented in Emile that a model pupil would need only

\footnotetext{
50 The New Zealand Spectator and Cook's Straight Guardian, 2 June 1852, p.2.

51 [Sic].

52 'Speeches of Maori Members', Te Waka Maori o Niu Tirani, Vol.12, No.21, 2 November 1875., Translation provided in niupepa.
} 
to read Robinson Crusoe to obtain 'the happiest introduction to natural education. ${ }^{53}$ In a similar vein, Kemp and his collaborators in Robinson Crusoe's publication may have assumed that the novel would serve as both a reflection to Māori of themselves (in Friday), and a model of progress, in the person of Crusoe himself. Moreover, one of the clear moral overtones of Robinson Crusoe is the ability of man, through hard toil and discipline, to civilise himself; that is, to provide himself with the trappings and possessions of Western civilisation. That Māori readers might find this a less than compelling model is never mentioned. While the deceit of its publication as a doubtful allegory may have turned away readers, or it may simply be that, despite the confident statements of the publication's backers, the chord struck by Defoe's tale of individual derring-do and civilisation's advent was not wholly palatable.

Robinson Crusoe and Pilgrim's Progress were not representative in length of the range of texts that made their way into the corpus of literature translated into reo Māori. As early novels, they were considerably longer than the norm of short pieces and excerpts which made up the bulk of texts published in reo Māori, both in niupepa and in bound volumes. However, they were good representations of a type of Victorian and Romantic literature which was wellrepresented in reo Māori translations. Nikki Hessell, writing in 2009, points to the global nature of this phenomenon, citing Sir Walter Scott's Lady of the Lake, translated into the Mohawk language, as a representative example of a larger and largely unexamined body of translation. Felicia Hemans' mid nineteenthcentury poem "The Hour of Prayer" is the most notable reo Māori example, appearing in three slightly different translations in schoolbooks and in the papers of Governor Grey. ${ }^{54}$ However, a number of other examples occur, mainly ensconced within the niupepa press. "The Hour of Prayer" first appeared in a reo Māori schoolbook in 1851, and in the niupepa press in 1852, while a pair of verse snippets appeared only in the Maori Messenger niupepa in 1849. These were an

\footnotetext{
${ }^{53}$ Pat Rogers, ed., Defoe: The Critical Heritage (London: Routledge \& Keegan Paul), p.52. Quoted in S. Rogers, p.190.

${ }^{54}$ Nikki Hessell, Nikki, 'Romantic Literature and Indigenous Languages: Reading Felicia Hemans in reo Māori' in Europan Romantic Review, Vol. 20, Issue 2, 2009, p.262.
} 
early verse from William Cowper's 'The Task: Book One', referring to a romanticised version of the primeval days of man; "Time was when clothing, sumptuous or for use, / Save their own painted skins, our sires had none"; and three verses from a longer sentimental poem by William Cullen Bryant, "The Murdered Traveller". The Māori Messenger, around the same time, was also fond of printing articles of 'exotic' travels, including 'Poison Valleys in Java', 'Travels in the Interior of Southern Africa', and 'The south Sea Islander and the Talking Chip'.

At times these excerpts could be remarkably tone-deaf to the culture in which they were being read; as with the wholescale grafting of Robinson Crusoe into a Māori context very different to that which its author wrote for, the inclusion of articles on 'South Sea Islanders' completely failed to take into account the likely circumstance and experience of reo Māori-literate readers in the late 1840s in Aotearoa. The story related in 'The South Sea Islander and the Talking Chip' plays out thus: a caricature of an unlettered 'Islander' is asked to deliver a message written on a piece of 'chip' to a literate man. On witnessing the man divine a meaning from scribbles on bark, he is overwhelmed by the revelation of writing explained to him by the kindly literate man, and immediately desires to be inducted into these mysteries. Perhaps the intent of such a piece's inclusion was merely to provoke in literate, 'civilised' Māori a feeling of accomplishment at being less credulous than the naïve islander here depicted. However it is not unlikely that the editors of the bilingual, governmentsponsored niupepa simply failed, like the translators of Crusoe, to give sufficient thought to how a reader from a Māori cultural background might approach a text from a different perspective, and did not consider that Māori might identify echoes of themselves in the South Sea Islander. Colonial government policy at the time around Māori was very much characterised by a desire to 'civilise' Māori; that is, of Māori becoming more and more like English people. An accepted facet of this government strategy was by presenting the best of English culture, as explained by Kemp: "If... by making the Press available... [Māori] should as a people be preserved, it will form a really pleasing exception in the 
Histories of Aborigines" ${ }^{\prime 55}$. Kemp clearly sees such a goal as admirable. However, this policy took for granted that Māori were a 'dying race', and involved the wholescale abandonment of many aspects of Māori culture important to the wellbeing of the Māori communities. In such a policy, Māori reading habits were envisaged as tools to turn against them, rather than tools by which Māori could inform themselves or develop their own adaptions. These government aspirations were not, evidently, always executed with the greatest of tact or imagination. The government editors of the Maori Messenger throw more light on the actual practice of this middle era of translation with their declaration of the niupepa's intent: "[It is] for imparting and disseminating information [to Maori], ... interspersed... with useful, moral, amusing and interesting lessons, suited to their comprehension and adapted to the wants of the colony". ${ }^{56}$

These avowed intentions, mixing 'amusing and interesting' with 'useful', may come closer to the truth; government policy of the time was to familiarise Māori with elements of English culture that might be seen as valuable, amusing or useful. The success of this strategy can be only guessed at. Many Māori certainly engaged with the translated literatures presented to them: the many early anecdotes of Māori eagerness for literacy and tales, and the later retention of literacy and fluency in English culture of Māori writers at the turn of the century show that readers engaged with the texts. Government aims of introducing culture may have been victims of their own success in this: Māori can by no means have been passive consumers of new texts, and as such rejected some texts, and imbued others with new phrases and their attendant meanings drawn from Māori culture and worldview. Hessel describes these texts as "not ...British... or Māori... but rather a New Zealand" text. ${ }^{57}$ This became more common, and particularly true as Māori-operated presses moved onto the printing scene, ushering in a new era of translation by Māori into reo Māori, with all the differing implications this brought.

\footnotetext{
${ }^{55}$ Henry Tacy Kemp, He pukapuka ako tenei, n.p.

${ }^{56}$ Wellington Independent, 21 July 1849, p.2. Quoted in S. Rogers, p.185.

57 Hessell, p.266.
} 
A range of texts were not religiously prescriptive, but nevertheless were overt about prescribing behaviour or morals. Some of these have been touched upon already as 'useful, moral' ${ }^{58}$ texts made available to readers by the colonial government during the late 1840s and early 1850s. An example not previously mentioned would be the Aesops and other fables commonly published in The Maori Messenger in the late $1840 \mathrm{~s} .{ }^{59}$ These were often accompanied by small expansions on a moral to be drawn from the text, sometimes addressed to a particular group within Māori society, for example, an exhortation to rangatira not to despise those of lower rank. ${ }^{60}$ The use of texts such as these by early government publications supports the thesis that using texts to communicate culture was a priority for this administration. Also notable, however, is that such use of texts was not limited to the colonial government, but was taken up by Māori printers themselves. Māori readers in positions of influence became producers of texts from the 1850s onwards, with the niupepa Te Hokioi, Te Puke Ki Hikurangi, and He Kupu Whakamarama and its successors. These men and other Māori translators had experienced themselves how a text, particularly one imparting new and varied ideas, could impart useful information that changed its readers' behaviour. In addition to prescribing many behaviours and practices through their own writing, these niupepa translated texts into reo Māori and used them as prescriptions or suggestions for the behaviour of their readers. Notable among these are the series of articles published in the Anglican Māori niupepa Te Pipiwharauroa in 1905, translations from a book identified as "Te Kainga me te Tane [The House and Husband]" and headed "A word to mothers" ${ }^{\prime 61}$. The three excerpts printed give advice on childcare, providing a pleasing environment for a husband, and household care. These were accompanied by several other moral homilies in the form of fables and stories in

\footnotetext{
${ }^{58}$ Wellington Independent, 21 July 1849, p.2. Quoted in S. Rogers, p.185.

${ }^{59}$ For example, 'Ko te raiona me te kiore', in Te Karere Māori, Vol.1, No.15, 19 July 1849, p.4.

60 Ibid.

61 'He Kupu ki nga Whaea: Te whaea raua ko Tana Tamariki', in Te Pipiwharauroa, No.88, July 1905, pp.2-3. Translation of original by Mrs. C Northcote, also see Te Pipi No.91. [trans. FDB].
} 
the early years of the twentieth Century ${ }^{62}$, including sources as diverse as writings from the early Christian saint John Chrysostom and question-andanswer dialogues taken from un-named English newspapers. The selection of moral literature introduced by Māori editors and translators to readers of reo Māori was a reminder that many Māori had integrated reading and writing into their lives, as an effective means of disseminating and receiving information, and as a means to change people's thoughts and behaviour. Prescriptive selection and editorialising of texts was by no means limited to one group of translators. Whether readers were quite so eager to integrate these helpful suggestions is more in dispute.

\section{Pacific connections, politics and language}

Significantly, translations from English texts did not make up the entirety of the texts available to reo Māori readers. These were the majority, but they were complemented by a small number of texts drawn from different cultures and, in some cases, different languages. A number of these texts made their way to reo Māori readers via an intermediary language - invariably English. Greek fables $^{63}$, long integrated into an English corpus of folk wisdom, made their way to reo Māori readers via the English language, as did Spanish proverbs. ${ }^{64}$ More lengthy texts adhering to this pattern include a scriptural history published in reo Māori in 1847, from an English translation (Descriptive guide to the stream of time) of a German original (Der strom der Zeiten) ${ }^{65}$ These few texts provide an interesting sidelight on an otherwise fairly cohesive corpus of translated English texts. Translators were, by and large, of English background, and the most successful printing presses were controlled by these organisations. It is logical that the texts deemed by these organisations most worthy of translation, and

\footnotetext{
${ }^{62}$ Te Pipiwharauroa in particular was very concerned about the health and cultural resilience of their Māori readers, and often published articles intended to disseminate best practice, a few of which were translated or drew on translated sources, but many of which were not.

${ }^{63}$ For instance, 'Te Kuri i te Whare Tarutaru', in Te Karere Maori, Vol.1, No.24, 22 November 1849, p.4.

64 'Taihoa', in Te Pipiwharauroa, No.65, July 1903, p.2.

${ }^{65}$ He Whakapapa Ara (Auckland: Williamson for the Church Mission, 1847). Translation of Friedrich Strass, A Summary of Scripture History to Solomon, based on Der Strom der Zeiten. BIM 365.
} 
those with which they were themselves most familiar, were English texts. However, the world in which the reo Māori corpus was being slowly built up was composed of more cultures and literatures than Māori and English alone. Interconnected by years of shared history and cultural exchange, it is hardly surprising that some texts of different origin, particularly European scholarship and well-worn stories, should be included in the body of literature familiar to translators, and therefore to their readers. The webs of Empire, and of a highlyconnected Nineteenth-Century world, certainly reached New Zealand, and affected its translated literature as part of cultural change.

Particularly interesting are two brief series of texts published in niupepa with their origins in the Pacific neighbourhood. The first is a translation of a letter ${ }^{66}$ sent by Queen Pomare IV, beleaguered monarch of Tahiti, to Louis Phillipe of France, begging him to reverse French occupation of the island, and referring repeatedly to her good relationship with London Missionary Society missionaries and British advisors (the Queen also wrote to Queen Victoria asking for aid). The letter is presented without explanation of its context, save the details of the sender and recipient. The 'Tahitian Affair' about which Pomare IV wrote was widely-reported in the early 1840s, and may have already been wellknown in Aotearoa. It was, moreover, an article which combined the appealing features of depicting an indigenous Pacific leader engaged in entreating the French crown and relying on the benevolence of the British Empire, and showing the French, whose own efforts at nationalism in New Zealand had been so recently thwarted, in a particularly unflattering light. However, it is also almost certain that the original of Pomare's letter was in Tahitian, as were earlier letters ${ }^{67}$ sent by her to various officials seeking aid. It is likely that the letter that appeared in reo Māori in Te Karere o Nui Tireni arrived there via an English translation and English media sources. The irony of this convoluted path, when the two island groups of Tahiti and Aotearoa were so close in language and sea

\footnotetext{
66 'Ko te Pukapuka o Pomare, te Kuini o Tahiti, Ki A Rui Piripi, Te Kingi O Wiwi' (reo Māori trans.), in Te Karere o Nui Tireni, Vol.4, No.3, 1 March 1845, p.10.

${ }^{67}$ Pomare IV Queen of Tahiti \& Pritchard, George, 1796-1883, Letters and prints (1843). Trove, http://trove.nla.gov.au/work/10953643; accessed 19 March 2015.
} 
room, is considerable. The letter's translation and publication places no importance on the links between New Zealand and Tahiti and the people's inhabiting these islands. However, it no doubt functioned for readers as a pertinent reminder that, mediated by imperial forces or not, the Pacific world and its indigenous groups made up a very present part of the cultural landscape which both colonial and Māori readers were enmeshed, a landscape in which similar themes of imperial experience were repeated again and again.

Published fifty years later in 1907, a series of reports on Hawaiian language, culture and history brought another colonised Pacific society to the attention of reo Māori readers. ${ }^{68}$ Uniquely, however, the series of four articles published in Te Pipiwharauroa emphasises Hawaiian language and literature, and focus largely on re-publishing Hawaiian traditional songs and legend, translated into reo Māori, and accompanied by the original text in Hawaiian, for ease of line-by-line comparison. Apart from a few texts provided by Catholic missionaries in liturgical Latin, the presentation of literature in a language other than English to Māori readers was very unusual ${ }^{69}$. The staff of Te Pipiwharauroa, however, were determined to use their niupepa not only as a method of communication, but also as an instrument for the collection, dissemination and retention of reo Māori and Māori literatures. They called for submissions of pēpeha and their provenance, and often published long collections of these in the pages of the niupepa, or waiata and stories. Their expressed aim in this was to retain this knowledge and communicate it to more Māori readers, lest such knowledge be lost and pass out of history. ${ }^{70}$ It could not be clearer that, at the turn of the century, this group of Māori men had comprehensively grasped the advantages of a print format, and were subverting it to their own ends with some success. They were, moreover, outward-looking, and often published news of the wider world. The conjunction of these two factors goes some way to explaining their interest in presenting readers with Hawaiian texts, both in the

\footnotetext{
68 'He Manuhiri no Hawaii', in Te Pipiwharauroa, No.114, September 1907, pp.4-5.

${ }^{69}$ I am not aware of any other examples; none are mentioned in the Books in Māori Index, though they may be present in the niupepa corpus.

${ }^{70}$ Te Pipiwharauroa, No.134, May 1909, p.11.
} 
original language, and translated into reo Māori. Reweti Kohere, the editor, writing as Tipiwhenua, stated in his preamble to one translated song that "In our opinion, it is a goodly thing to compare our stories of old to those of our cousins from far-flung islands, to see if the stories themselves are cousins." ${ }^{71}$ The article goes on to present a number of Hawaiian songs, glossed line-by-line into reo Māori, with a commentary on the figures presented in the text and their possible links to figures in both Māori stories, and in the wider Pacific. In the four other newspaper pieces Te Pipiwharauroa ran on Hawaiian culture, they focus heavily on building connections between Hawaiian and Māori culture, history and language, making a desire and scholarly intent to find connections between the two cultures very evident. It is evident that, at the turn of the century, Māori translators at least considered their readers to be in need (or want) of articles both showcasing the wider world, and weaving connections from this to the world of their readers.

This is a new angle on the didactic aims of mostly colonial-translated texts from earlier in the century: where earlier texts had sought merely to instruct, by the turn of the century, texts from other cultures were explicitly translated in order to engage their readers in a wider network of ideas and literatures. Where readers had always been active participants in their own reading, they now had the opportunity to read texts that encouraged this attitude. With these texts, it could be said that for the first time texts enabled a syncretic approach to reading: presenting new literatures in reo Māori for Māori to assimilate into evolving Māori culture, rather than new literatures designed, in reo Māori, designed to assimilate Māori into a foreign culture. The distinction is perhaps subtle, but it was of overall importance.

\section{Paratexts}

An additional feature of many reo Māori-translated texts were the paratexts attached to them. While the actual content of translated texts was often slightly changed, paraphrased or cut-down in the process of translation, it

\footnotetext{
${ }^{71}$ John Tamatoa Baker, Kohere, Reweti (as 'Tipiwhenua')(trans.), 'He Waiata No Hawaii', in Te Pipiwharauroa, No.116, November 1907, p.4.
} 
remained bound by the fact it must represent the original text. The paratexts attached to the original text, however, could and did differ wildly form any original paratext. Paratext, any text attached to a piece of literature that relates to it, can refer to items as diverse as the titles placed above a text, reviews referring to it, or notes explaining its provenance and meaning, all of which were at times attached to texts translated into reo Māori. A paratext "can be physically attached to the narrative vehicle"72, but does not have to be. The majority of paratexts in this discussion are physically attached to the text which they expand upon, although a few are not. The great strengths of paratext are that, as they are not necessarily set by the author of a work (or adhered to when set), they can be manipulated or written by an editor, translator or printer in order to communicate or emphasise different parts of a text to the reader. As influencing the behaviour of readers through the texts available to them was at the least an implicit goal for almost all printers of reo Māori texts, paratexts were an invaluable method, and can often be found expanding upon some unfamiliar text or genre as it was introduced to readers.

A great many texts, particularly in the earliest days of printing dominated by religious matter, were firmly focussed on ensuring that their readers did not miss the message of the text. Early allegories such as the Samuel Wilberforce translations discussed above could be accompanied by 'reading guides'; question-and-answer dialogues intended to draw out the Christian morals contained in the allegorical stories. Asking questions of the reader or expounding on the morals of the story remained a popular technique throughout the remainder of the century. Aesop's (and other) fables were commonly published in Te Karere Maori / The Maori Messenger in 1849, and often accompanied, or even headed, by the moral they were intended to illustrate. The Lion and the Mouse, published in The Maori Messenger, was in fact followed not only by an explanation of the moral (apparently: "a lesson for chiefs, that they should be kind to their children, their slaves, and their followers" ${ }^{73}$ ), but also a re-iteration of a similar message via a snippet of reo Māori proverb, "ko wero ko ponga ka

\footnotetext{
72 Abbott, p.239.

73 'Ko te raiona me te kiore', in Te Karere Māori, Vol.1, No.15, 19 July 1849, p.4.
} 
tika"74. "The Pen and the Sword" is introduced as an 'ancient Jewish apologue', and "The Dog in the manger" headed with the italicised, expanded moral "Lest a man fall by this thing, not enjoying your possession, but on the other hand withholds it from others, and will not release it - that is a sign of a perverse nature."75 Other types of lesson are also expanded upon in paratexts. In fact, it was not unusual for a lesson to merely drop in a tag or two excerpted form a longer European work to support its own points, rather than supporting the translated thought with other points. The pseudonymous contributor 'Nohopari' (Apirana Ngata), musing on the delights of home in 1909, used a rather loose translation of the 1820 s song "Home Sweet Home" to illustrate his gentle elegy to feelings of nostalgia and longing. ${ }^{76}$ Likewise, the explanatory texts attached to the Hawaiian waiata provided to Te Pipiwharauroa in 1907-8 are anxious to ensure that their readers do not overlook any meaning, particular in the connections between Hawaii and Māori, which the translators wished them to absorb.

Paratexts also made claims to the reader about the worth of a text; for example, a speech by Prime Minister William Pitt was reported in full in Te Pipiwharauoa in 1903, and headed with the description "One of the greatest speeches ever heard in the English Parliament". Other texts instruct their readers to closely peruse the text in order to get the most from it. Te Pipiwharauroa's publication of excerpts from Hamlet at the end of the century exhorted its readers to closely read the extract, and gain what understanding they could form its unfamiliar words. The concluding paragraph after the extract itself relates the King's speech to Hamlet to the problems of debt and lending, and uses it as a warning to the reader to avoid such traps. ${ }^{77}$ A second function of such paratexts as the editorial comments on Hamlet is to link one literary text to another for readers, joining the literary dots in order to further emphasise a

\footnotetext{
${ }^{74}$ Wero - an archaic spelling of 'whero'; 'ponga' - a corruption or dialect translation of 'pango'. 75 'The Sword and the Pen' 'He Korero-tito: Te hoari me te penetuhituhi', in Te Karere Maori, Vol.1 No.18, 30 August 1849, p.4.

76 'Te Kainga Tupu', (trans. Apirana Ngata), in Te Pipiwharauroa, No.141, December 1909, p.10.

77 'He Korero no te Matauranga: Hamlet', in Te Pipiwharauroa, No.172, September 1912, p.11. [trans. FDB]
} 
point about behaviour or useful knowledge. An excerpt from the writings of early Orthodox Christian Saint Chrysostom, published in Te Pipiwharauroa in 1909, and the 1846 volume "He Korero Tenei mo Ani Kanara [A story of Ann Chandler]" both make use of ancillary texts; sayings and wisdom from a historical figure in the case of Chrysostom, and a maudlin tale of a pious girl's death in the case of Ann Chandler; in order to link the sentimental texts to scriptural morals and behaviours. These texts encouraged the reader to think critically about the content they had just consumed: Kohere advised readers that his understanding of the passage set before them was incomplete, and therefore "it is left to the understanding of the reader to understand, secondly to ponder, and thirdly to speak and translate these troublesome words". ${ }^{78}$ He was not alone in asking readers to engage with the texts they read, to critique and disseminate them in appropriate manners. All these techniques, however, could also be used (and were) in order to direct readers' ideas and behaviour.

By no means were all translated texts, however, accompanied by such texts. A considerable number of translated texts, on the contrary, are only accompanied by minimal paratexts, such as their title and author, have missing paratexts, perhaps to the point at which the text becomes unidentifiable, or have paratexts that either mislead the reader as to the text's provenance, or elide important parts of the texts origins. ${ }^{79}$

When a large proportion of texts presented to readers selected largely for their instructional merit, at first it appears a curiosity to have an approximately equal number of texts without any additional markers of identity or expansion. However, there are several reasons l'd like to propose for the absence of complete or accurate paratexts in translated texts. Firstly, some texts may have been considered as needing no further introduction, perhaps because

\footnotetext{
79 'He Kupu ki ngā Whaea', in Te Pipiwharauroa August 1905, is unidentifiable, and its source remains a mystery. 'The Dead Traveller' and 'Poisonous Valleys', both published in The Maori Messenger 12 December 1849, are unattributed, and 'The Poisonous Valley' is mis-titled. 'The Dying Year', published later that month in the same publication, attributes the text to a very dubious source; other newspapers syndicating the story in England disagree with the author given here. By my sampling the proportion of texts with missing or incomplete paratexts in the niupepa is about half.
} 
readers were already familiar with them. For example, Robinson Crusoe, as already discussed, became a well-established part of the cultural corpus for many Māori, and later reports on the story ${ }^{80}$ did not waste words explaining it, making a fairly safe assumption that their audiences were familiar with them. This confidence in the audience's ability to recognise and mentally place a text may be at play in, for example, the many hymns published in later niupepa without provenance or details. ${ }^{81} \mathrm{~A}$ similar situation may be at play for the series of animal fables and moral fables published in the 1840s and 1850s in Te Karere Māori, which are seldom attributed, or if so, attributed with incomplete or incorrect details, as the fable of the "Sword and the pen", designated as an 'Ancient Jewish Apologue' in the English portion of the bilingual text, and unidentified in reo Māori. ${ }^{82}$

The publication of an unattributed 'dream of Martin Luther' published in He Kupu Whakamarama is similar; unattributed, it appears to be a story repeated in many different texts and languages without a source. ${ }^{83}$ However, an additional factor may be at play in the reporting of fables in niupepa - in that the form was similar to Māori stories, as well as to English newspaper readers, and may well have needed no further introduction. Other texts with missing paratexts and attribution, however, may have been more in need of identification, such as the unattributed article "Te Wharau Whakamate" 84 , a translation of the talk "Poison Valleys in Java", originally given as a talk in 1831 in London and repeated in various magazines around the world. Similarly, "Te Mahi Hapati", a homily on the Sabbath, is attributed only to "a large newspaper of England". There are two distinct possibilities here; the first that for whatever reasons, editors and printers did not consider attribution necessary for their readers. The second, perhaps more likely, is that editors and publishers did not know the correct attributions for the pieces they published. Some pieces of news

\footnotetext{
${ }^{80}$ For example in Te Wananga, Vol.3, No.43, 25 November 1876, p. 428.

${ }^{81}$ For example, 'He Himene', in Te Pipiwharauroa, No.102, September 1906, p.2

82 'The Sword and the Pen' 'He Korero-tito: Te hoari me te penetuhituhi', in Te Karere Maori, Vol.1 No.18, 30 August 1849, p.4. Translation of 'The Sword and the Pen'.

83 'He Moemoea', in He Kupu Whakamarama, No.4, June 1898, p.1

84 'Te Wharua Whakamate', in Te Karere Maori, Vol.1, No.25, 6 December 1849, p.4.
} 
circulated from newspaper to newspaper throughout the Imperial world, sometimes poorly attributed, and niupepa not uncommonly simply translated some of their articles from English-language newspapers. If English sources were unattributed, neither did translators attribute their reo Māori pieces. For readers, the impact of sometimes convoluted journeys of texts to a page printed in reo Māori was to lengthen the distance between the author of a text and the reader, opening up opportunities for misinterpretation. A lack of information did not leave merely a vacuum of information, but also an opportunity for readers to fill in the gaps with their own interpretations of the veracity, significance and source of a text. These suspect paratexts could therefore function as a vexation for the author and reader, but, conceivably, as a tool for publishers. A converse effect may also have come into play, the absence of paratexts clearing space for the text to speak for itself.

A third effect of the absence, incomplete state or inaccuracy of paratexts was to falsify information, deliberately or incidentally. While some texts, for example "The Complaint of the Dying Year", misattributed to Jane Taylor ${ }^{85}$, seem innocuous, some texts with incomplete or incorrect paratexts are so bizarre as simple omissions to make their inclusion indicative of some larger preoccupation or priority. A prominent and very puzzling example are the pakiwaitara, traditional stories, published in Te Pipiwharauroa at the beginning of the twentieth century, and identified as "Stories from the book of George Grey" ${ }^{86}$ Several pakiwaitara are featured over several issues of the paper, under the designation "from the book of George Grey", the stories including knowledge on 'Tangaroa', 'Rangi', 'Tane', and 'Maui', all well-known figures among Māori iwi. An early piece published in the niupepa mentions Ruataniwha, no less, an area near to both the settlement where the niupepa was printed, and where many of its readers lived. These stories, as will be discussed in chapter three, were collected with the help of knowledgeable Māori sources and had their origins in

\footnotetext{
85 'Te Matenga o te Tau', in Te Karere Maori, Vol.1, No.26, 20 December 1849, p.4.

${ }^{86}$ George Grey, 'Ko te Patunga o Tau-a-Porirua: He taniwha no Heretaunga', in Te Pipiwharauroa, No.132, March 1909, p.11.
} 
many different iwi's stories collected from around the country. ${ }^{87}$ To identify the stories only as 'from the book of George Grey', then, is somewhat surprising. The iwi-specific origins and original contributors of the stories are completely excluded from inclusion here. Possibly the editors of the niupepa expected their readers to know the origins well already, or possibly they were unwilling to expend the effort to seek out and add this information to the ready-made text of Grey's book, already published in reo Māori. More probably they were unconcerned about the origins and gave the omission little thought, which in itself points to the success of Grey's own versions of these stories, and the elision of knowledge about such texts that, at later dates, these niupepa would strive to preserve as they strove to preserve pēpeha and other Māori texts in their pages.

Māori readers must have been made uncomfortably aware, in reading texts like these, of the complicated nature of cultural appropriation between the two cultures, and the extent of the assimilation of Māori stories into Pākehā control. It may have been that the stories here included were an expression of Māori bringing these Pākehā-edited stories back into a very Māori-dominated context in the niupepa. However, they are in marked contrast to the general trend of translated texts, which were an expansion of the written reo Māori corpus with outside material - in the partial attributions of these stories, Māori culture and historical presentations of reo Māori passed into the corpus available to Pākehā, available in English, and all the more available for misunderstanding. The usual flow of textual transmission in reo Māori translation was reversed with these stories.

Within forty years from the beginning of the nineteenth century, Māori reading developed from a foreign concept into a widely-used means of communication encompassing a wide range of texts. With the advent of missionaries in New Zealand, Māori were able to learn the skills of writing and reading, and quickly made use of these skills to learn, to communicate with

\footnotetext{
87 Sir George Grey, Polynesian Mythology and Ancient Traditional History of the New Zealand Race (Auckland: H Brett, 1885), p.viii.
} 
missionaries and then with each other and the colonial government, and to inform themselves about new ideas, ideologies and literatures. To begin with, Māori readers in New Zealand were limited to reading almost exclusively ecclesiastical material produced by the missionaries. These texts diversified from the 1840s onwards, however, and legal texts and government papers began to appear, as did a wider range of moral literature and, from 1842, the niupepa. Within the pages of the niupepa, a very eclectic range of literature was available to readers of reo Māori for the first time; largely texts written for a reo Māorireading audience, but a significant number of English-language texts alongside them. These texts, particularly the longer texts, reflected the aspirations and machinations of their publishers, as each text sought to 'entertain or inform' its readers. All, however, provide a glimpse into the curated range of texts available to reo Māori readers. Some of these texts hit their intended marks, other did not. The reception of many texts can only be guessed at through conjecture, in the absence of evidence as to the thoughts of the elusive readers. Something can be guessed at, however, through the paratexts and associated other writings accompanying texts. These often offered identifying information about the texts. What was here included, what was excluded, and what was elided in explaining the texts reveals yet more about the context in which the translated texts were read. Particularly towards the close of the nineteenth century, paratexts written by Māori editors in reo Māori niupepa provide an insight into what some readers wanted translated and read by their peers. Readers were able to access a variety of texts, and were able to encounter many different pieces of literature thereby. Accompanied constantly by directives to be entertained, to learn, or to understand a particular message, texts rarely stood alone, but were integrated into a complex context of printers' and government agendas, past readers' explanations, and an expanding, but ever more print-bound world. 


\section{How Māori Read}

Māori reading of translated texts is, of course, informed by the manner in which Māori read any and all texts in the latter half of the $19^{\text {th }}$ Century. Although readers tend to pass lightly over a text, the 'trajectory a reader takes through books... mostly vanish(ing) from view'88, a partial picture of long-dead people's reading habits can be built up from fragmentary evidence around reading, in this case, largely from niupepa evidence and disapproving articles. The context in which reading in New Zealand was generally practised, the favoured mediums of reading, and Māori reading practices described or prescribed by niupepa all provide clues to how Māori readers in this period carried out their reading.

\section{New Zealand Reading Practice}

Reading was a popular occupation around the Western world in the $19^{\text {th }}$ century. Martyn Lyons states that 'by the 1890s, 90 per cent literacy had been almost uniformly reached [in Europe] and the old discrepancy between men and women had disappeared. This was the 'golden age of the book' in the West: the first generation which acceded to mass literacy. ${ }^{89}$ Public lending libraries became widespread, with 553 across England by 1880 and working-class readers swelling their ranks. ${ }^{90} \mathrm{New}$ Zealand was not immune to these changes, and in fact, public enthusiasm for reading and lending libraries in this country far outstripped demand at British libraries. J. E. Traue's research demonstrates that over this same period in New Zealand, public libraries exploded in popularity, with a staggering one public library per 1,529 people in $1878^{91}$, approximately

\footnotetext{
${ }^{88}$ Lydia Wevers, Reading on the Farm: Victorian Fiction and the Colonial World (Wellington: Victoria University Press, 2010), p.23.

${ }^{89}$ Martyn Lyons, 'New Readers in the $19^{\text {th }}$ Century: Women, Children, Workers', in Guglielmo Cavallo and Roger Chartier (eds.), A History of Reading in the West, (Amherst: University of Massachusetts Press, 2003), pp.313-344, p.313.

90 Lyons, p.332.

91 Traue, 'The Public library explosion in Colonial New Zealand', Libraries \& the Cultural Record, Vol. 42, no. 2, 2007, pp. 151-164, p.152.
} 
300 libraries for a population of around $458,007 .{ }^{92}$ These rates only rose over the period to the beginning of the twentieth century. ${ }^{93}$. These libraries, unlike the often urban concentration of institutions that sometimes occurred in Britain, were not confined to larger urban areas. 'By the year 1908,' Traue states, 'there was hardly a population centre in New Zealand that lacked a library... in 1906 the county of Otamatea had six libraries for 2,921 people, ${ }^{94}$ as did the small areas of Cheviot and Weber. ${ }^{95}$ This was 'the highest density... of libraries to total population... ever reached in any country or state. ${ }^{\prime 96}$ Moreover, 'between 1873 and $1896 \ldots$ between 7 and 10 percent of the total population were reading materials from these libraries. ${ }^{97}$ Traue goes on to state that "on the evidence provided by the [census] statistics, New Zealand was, by the third quarter of the nineteenth century, a veritable paradise for readers, with the formation of public libraries following closely on the heels of the settlers as they spread out across the country. ${ }^{98}$ Most of these readers, additionally, read fiction. In Europe, the public 'devoured cheap novels... in the first quarter of the nineteenth century, [the novel's] status was assured... it became the classic literary expression of triumphant bourgeois society.' ${ }^{99}$ The New Zealand public, likewise, were voracious readers of novels, and according to Traue, "by the end of the century most of the smaller libraries were buying fiction only. In $1913 \ldots 89 \%$ of the purchases of all [smaller and provincial libraries] consisted of fiction.' ${ }^{\prime 00}$ Despite the eager reading habits of these readers in a 'veritable paradise for readers' ${ }^{101}$, however, these habits were under scrutiny. A New Zealander, according to New Zealand promotional material, should be an erudite, educated man. A New

\footnotetext{
92 Population figures from 'Results of a Census of the Colony of New Zealand for the night of the 3rd March 1878' The New Zealand Official Yearbook, 1878; URL

http://www3.stats.govt.nz/historic publications/1878-census/1878-results-

census.html\#idsect1 1 5058; accessed 2 April 2015. Figures show population exclusive of Māori 414,412 , and Māori population estimated at 43,595.

93 Traue, op. cit., p.152.

${ }^{94}$ Traue, op. cit., p.152.

95 Traue, op. cit., p.152.

${ }^{96}$ Traue, op. cit., p.152.

${ }^{97}$ Traue, op. cit., p.152.

${ }^{98}$ Traue, op. cit., p.153.

99 Lyons, op. cit., p.314.

100 Traue, op. cit., p.160.

101 Traue, op. cit, p.153.
} 
Zealand Company propagandist, writing in 1844 , states that 'A well-conducted colonist is of necessity a reading man: debarred from the more frivolous amusements of the mother country, he has no other resource but in books' ${ }^{102}$ The 'superior nature of the New Zealand colonist' ${ }^{103}$ was in his dedication to learning. In presenting such a picture of their ideal colonist, the New Zealand Company provided an aspirational model of their colonists' futures; of a modern autodidact, a dedicated and sober reader, and an erudite, educated man. a figure which, prospective migrants were to believe. Whether or not reading novels could mould such a man into being was quite another question. Various societies and philanthropists in Europe established libraries of science, natural history and other practical topics, in the hope that 'a range of useful literature, to promote 'rational recreation' ${ }^{104}$, would soothe class tensions and elevate the working classes into 'a consensus of bourgeois values'; a strategy which, Lyons noted, seemed to be working in the United Kingdom. ${ }^{105}$ Such a strategy of mollification may have been a factor in New Zealand, as reading was explicitly contrasted in prescriptive texts with more 'frivolous amusements' and the 'debasing influence of the tavern'. ${ }^{106}$ For the settler, it was a false dichotomy between the printed page or the demon drink, and nothing prevented many from turning to both. In any case, as the literate proportion of the population in Europe and England rose, so too did prescriptions of how this literacy should be exercised. These prescriptions did not fail to make their way into the preoccupations of New Zealand settler society, which looked toward global and English trends as it built up its own version of a 'civilised society' in Aotearoa.

Despite the high rates of library establishment and book lending, the quantity of reading that occurred in Victorian New Zealand did not, in the eyes of

\footnotetext{
102 "Review", New Zealand Journal, 6 July, 1844. in J. E. Traue, 'The Public library explosion in Colonial New Zealand', Libraries \& the Cultural Record, Vol. 42, no. 2, 2007, pp.151-164, p.154.

103 Traue, p.154.

104 Lyons, p.334.

105 Lyons, p.334.

106 "Review", New Zealand Journal, 6 July, 1844. NZ Company propagandist, quoted in J. E. Traue, 'The Public library explosion in Colonial New Zealand', Libraries \& the Cultural Record, Vol. 42, no. 2, 2007, pp.151-164, p.154.
} 
some commentators, make up for its poor quality. In line with European trends, reading largely for educational purposes was giving way to reading for entertainment, a very different type of content, and moreover, threatened by the rise of newspaper and magazine formats. The 'reading revolution' of the eighteenth and nineteenth centuries was a change 'from intensive reading, deliberate and reverential, of a small number of texts... to extensive or promiscuous reading ... covering a wide range of subjects for instruction, information, and private entertainment.' 107 This 'promiscuous reading' was in itself, William J. Gilmore argues, an agent of modernisation that did not require urbanisation $^{108}$ - rather it took modern thought out of the metropole - in New Zealand centres such as Wellington and Auckland, or even metropoles located in different countries, and into smaller centres and rural regions (incidentally, the area in which the majority of Maori lived) ${ }^{109}$. It quickly became apparent that the new kind of society emerging in New Zealand was 'born modern'110, with widespread reading both in urban and rural areas. The novelist Anthony Trollope, visiting New Zealand in the 1870s, included among his favourable impressions of the small town 'Tuapika' that 'in all these towns there are libraries, and the books are strongly bound and well thumbed. Carlyle, Macaulay, and Dickens are certainly better known to small communities in New Zealand than they are to similar congregations of men and women at home. ${ }^{111}$ In a similar vein, the private libraries at Brancepeth Station in the Wairarapa demonstrate a well-used and well-loved collection, sections of which were open to (and used by) workers both clerical and labouring around the remote station ${ }^{112}$. The books themselves tell the tale of their use, with split spines, dog-ears and marginalia; echoing the 'well-thumbed' state of public library collections. The modern reader's

\footnotetext{
107 Traue, op. cit., p.157.

108 William J. Gilmore, Reading Becomes a Necessity of Life: Material and Cultural Life in Rural New England, 1780-1835 (Knoxville: University of Tennessee Press, 1989), p.353.

${ }^{109}$ Basil Keane, 'Te rāngai mahi - Māori in the workforce - The rural workforce', Te Ara - the Encyclopedia of New Zealand; URL www.TeAra.govt.nz/en/te-rangai-mahi-maori-in-theworkforce/page-3; accessed 26 February 2015.

${ }^{110}$ Caroline Daley, 'Modernity, Consumption and Leisure', in Giselle Byrnes, ed, The New Oxford History of New Zealand (Melbourne: Oxford University Press, 2009), 423-440.

${ }^{111}$ Anthony Trollope, "New Zealand: Being a Portion of 'Australia and New Zealand (London, Chapman and Hall, 1874), p.53.

112 Wevers, Reading on the Farm, p.28.
} 
preference for fiction, however, was still a matter of concern and debate in New Zealand. Although autodidactic learning through dedicated reading was a popular ideal for the reading public, the reality of reading practice (so far as it can be reconstructed) was very different. Traue explains that 'to the bewilderment and consternation of politicians, educators, and newspaper editors... popular fiction dominat[ed] new purchases and borrowing. ${ }^{\prime 13}$

A taste for popular novels was not, however, the worst of the newly literate classes' sins. Worse yet was his (or, perhaps, her) predilection for reading not only objectionable content, but objectionable debased forms of print: newspapers and magazines. Sir Robert Stout, one such educator and dedicated reading campaigner, was particularly affronted by what he saw as a lack of serious reading by the youth of New Zealand. In a much-reprinted pamphlet called "How and What to Read", Stout noted that, while 'in the houses and boardinghouses I have visited I have not seen a single young person reading a serious book ${ }^{114}$, other forms of literature were found in abundance. Newspapers and magazines are plentiful, and our newspapers contain varied reading. Generally in the Saturday paper there are interesting extracts, short stories, and a few columns of science notes, and references to new books. Such newspapers have become a substitute for books. ${ }^{115}$

While not, in fact, wholly condemning the content of newspapers and magazines, Stout was nevertheless concerned at the implications of aimless reading encouraged by a newspaper format, and as 'the reading of serious books was not popular'116, he determined that action must be taken, and explained in his pamphlet the dangers attendant on a newspaper-reading habit:

The danger of confining the reading to newspapers, however well the selections that appear in them may have been chosen, is that the reading

\footnotetext{
113 Traue, op. cit., p.158.

${ }^{114}$ Robert Stout, How and What to Read (Auckland: Book Exchange, 1908), n.p..

115 Stout, n.p.

${ }^{116}$ Stout, n.p.
} 
becomes desultory and aimless. ... the question is, How can [this] be altered? I propose to deal with the subject. ${ }^{117}$

Stout goes on to urge readers to 'read the best that can be said on [any subject] by the best men'118, and gives by way of example short reading lists in the suggested subjects of history, biography, travel, science, sociology, philosophy, and religion. His focus, however, remains on the necessity of 'deep' reading and studying a subject in depth. Novel-reading is not explicitly mentioned, but its recreational nature can have been considered but of little use in Stout's course of study. For Stout, the form and content of a popular New Zealand diet colluded to cheapen the reading habit and sabotage the development of an informed mind in the New Zealand reader.

Leaving aside the question of whether a tour of boarding house lounges constituted a good sample of a nation's reading population (Traue's library establishment figures alone give it something of a hyperbolic cast), Stout's analysis relies on the explicit assumption that a population of 'desultory' readers cannot be a good thing. Intentional and serious reading leading to selfimprovement, and the consequent improvement of a nation increasingly populated by well-read, erudite men, is Stout's proscription. This was echoed through the media of the time.

This anxiety over reading habits can perhaps be traced to the rapidly evolving perceptions of civilised behaviour current at the time Stout was writing. The 'reading revolution' of the late Eighteenth Century had created, almost out of nowhere, a huge number of people who, for the first time, were able to read in greater numbers and from a wider range of texts than ever before. However, a self-taught or well-educated reading class did not spring from nowhere, nor had it been the only mode of reading in the European reading society from which New Zealand's Pākehā settlers sprang. Reinhard Wittman refers to reading practice in emerging modern Europe as 'unruly reading, a mode of reading that was naïve, non-reflexive and undisciplined, and for the most part performed

\footnotetext{
117 Stout, n.p.

118 Stout, n.p.
} 
aloud. ${ }^{119}$ This was reading of tables, rules for weather and farming, devotional works and chapbooks - the broken-up, non-narrative reading of a people not accustomed to reading for individual pleasure, and often aloud. Colonial New Zealand may have been 'born modern', in that the settlers which soon flooded the country after 1840 came from modern, rapidly industrialising societies. It may be that the customs they brought with them, such as old, 'unruly' and uneducated processes such as the reading practice described above were undergoing a process of informal review, being proscribed in order to move ever more swiftly and firmly into the modern world. The strictness with which Stout pressed for a certain type of reading, and with which libraries expressed their concern, may well have been a reaction against the perceived unworthiness of retaining past habits.

This anxiety over a nation's reading habits and whether or not they were 'suitable' was echoed in the Māori press. However, the prescriptions and anxieties came from different places and had a different focus to those levelled at English-language readers. Repeatedly, observations of Māori reading practices were no sooner made than improvements to such practice were prescribed. However, before examining the remedies suggested by various figures for unsatisfactory Māori reading practice, these practices must be examined.

The first requirement for the development of reading habits is, of course, a reading population. Māori literacy was such that missionaries were confident of high literacy rates in the 1840s, and Bibles were so popular that one existed in reo Māori for every second m1aori adult in the country. ${ }^{120}$ McKenzie and Paterson ${ }^{121}$ both propose different figures or ranges of figures, but agree on two pertinent points. Firstly that some groups of Māori (those employed by or trading with Pākehā, those who had attended mission schools, those living in or

\footnotetext{
${ }^{119}$ Reinhard Wittman, 'Was There a Reading Revolution at the end of the Eighteenth Century?' in Guglielmo Cavallo and Roger Chartier (eds.), A History of Reading in the West, (Amherst: University of Massachusetts Press, 2003), pp. 284-312, p. 290.

120 McKenzie, p.28.

${ }^{121}$ Lachy Paterson, Colonial Discourses: Niupepa Māori 1855-1863 (Otago, Otago University Press, 2006), p.38.
} 
near Pākehā settlements) were more likely to have literacy skills, and secondly that the proportion and dispersal of literate Māori was sufficient that most communities would have had at least one member 'able to read and write.'122 Apirana Ngata gives one example of a reading community on the East Coast. Regarding the arrival of books in the area, Ngata stated that 'few people possessed them' in those early days, but that this did not stop the content of the books reaching a wider audience than those who could afford to buy a volume. 'Most people', Ngata continues, 'encouraged the individuals who owned the book to read out the words to them. The Māori are still like this... one speaks, and the many listen.' ${ }^{123}$

Those who did own books, however, often prized them highly. After the turn of the century, a significant number of private libraries owned by Māori scholars demonstrated that this feeling survived. Makereti Papakura, the wellknown Whakarewarewa guide and later anthropological scholar, was photographed sitting in her whare surrounded by both Māori and Pākehā taonga: including a prominent stack of books at her elbow and a handsome enclosed bookcase full of bound volumes. ${ }^{124}$ Those titles that are discernible are classics of the era, including Kipling's Kim and a bound history of Punch. Despite the evidently staged nature of the photographs ${ }^{125}$, it is evident that Makereti was a highly literate and even literary person, who later became a notable anthropological scholar and took a BSc at Oxford University. To take another example from approximately the same era, Golan Maaka, a notable doctor from the East Cape, owned a considerable library and was an avid reader (and writer). When the library was opened to Bradford Haami, his biographer and grandson, after Maaka's death, Haami notes the care with which the collection was treated

\footnotetext{
122 Paterson, Colonial Discourses, p.38.

${ }^{123}$ Apirana Ngata, 'The Māori and Printed Matter', in History of Printing in New Zealand (Wellington, 1940), pp.48-49, p.48.

${ }^{124}$ Mandy Treagus, "From Whakarewarewa to Oxford: Makereti Papakura and the Politics of Indigenous Self-Representation", Australian Humanities Review;

http://www.australianhumanitiesreview.org/archive/Issue-May-2012/treagus.html. Photograph original Alexander Turnbull Library, New Zealand News Collection, PA1-Q-012-39-1 125 Parkerson, two views of Tuhoromatakaka, in Weekly Graphic and New Zealand Mail, May 1910, in Pitt Rivers Museum, University of Oxford(Photographic Collection), 1998.277.19A, 1998.277.20A, 1998.2277.22.
} 
and the strict conditions under which it was made available to him. 'Reverence for books', he notes, 'and for the information contained therein, was still very much a part of the mindset of the old people. ${ }^{126}$

Haami writes about a literacy and reverence for the written word attained by rural Mãori communities in the early part of the twentieth century. Haami remembers that 'every day we saw [Maaka] reading or writing. His vast collection of books ranged through every conceivable subject.. ${ }^{127}$ Haami and his brothers were also 'astounded at the large number of books in the home,'128 and picked up their own taste for reading as discovery and entertainment. It is likely that the Maaka whanau library was largely in English; subjects cited include a wide range of histories and natural history subjects. However, Golan, a scholar and school-teacher from a young age, ${ }^{129}$ spoke and read Māori, although he worried that his speech was not perfect ${ }^{130}$, and his library also included texts in reo Māori, with 'Māori periodicals such as Te Puke ki Hikurangi, Matuhi, Te Wananga, Te Kopara, and... Te Whetumarama o te Kotahitanga... piled to the roof'. ${ }^{131}$ It would be surprising if these reverent attitudes toward book collecting, writing and reading sprang from nowhere. In fact, they very likely owe their roots to the reading culture of the late nineteenth century among Māori, built partly upon a reverential attitude to the scriptural texts that were the first works availabel to Māori readers, and to the niupepa which made up a large part of the reading material available to readers of reo Māori. As demonstrated by Ngata's comment above, not everyone had access to books, even when they had sufficient reading skills to interpret them, and as such a book was often prized for rarity. Some of this dearth of material was filled by the niupepa. However, the distinction modern readers make between newspapers, books and other

\footnotetext{
${ }^{126}$ Bradford Haami, Pūtea Whakairo: Māori and the Written Word (Wellington: Huia Publishers, 2004), p.9.

${ }^{127}$ Haami, Pūtea Whakairo, p.9.

128 Haami, Pūtea Whakairo, p.9.

${ }^{129}$ Bradford Haami, 'Maaka, Golan Haberfield', Te Ara - the Encyclopedia of New Zealand; http://www.teara.govt.nz/en/biographies/4m1/maaka-golan-haberfield; accessed 11 February 2015.

130 Bradford Haami, 'Maaka, Golan Haberfield'.

131 Haami, Pūtea Whakairo, p.9.
} 
forms of printed material was not made to the same extent in the nineteenth century. In the early days of niupepa, Māori referred to them not by the term 'niupepa', but by a catch-all term for any printed material, 'pukapuka'. Considering the diversity of the printed materials (catachisms, gospels, multiplication tables, alphabets, legal notices, tickets and more) available to Māori at the time when a term for them first became a necessity, this is not very surprising. Later, when 'niupepa' developed as a term, Lachy Paterson makes the point that they were somewhat different to modern newspapers, being smaller, composed of often as few as 4 and seldom more than 12 pages, and sometimes containing little 'news'. However, the term 'pukapuka' survived as a catch-all term for some time,. It is important to note that as distinguishing between different forms of print appears to have been of limited interest to the original readers of the era, it may also be a less than useful distinction in the study of these readers' habits.

Books were not, of course, the only reading material available to Māori readers; a great deal of reading would in fact have taken place in the reo Māori press, the niupepa. Fewer than fifty bound books were ever issued in reo Māori, ${ }^{132}$ and the majority of printed reading material available to Māori readers was in the form of bills, sheets, printed Acts and, most pertinently, niupepa. The first of these was Te Karere o Niu Tireni, issued for the first time in 1842, and closely followed by forty-odd ${ }^{133}$ niupepa publications, varying in the number of their issues between a single issue, and 180 issues. Although these publications were often produced on a shoe-string budget and in provincial areas, their correspondents signed their letters with addresses from disparate locations, suggesting a wide readership. Moreover the content of the news in niupepa marks many of them as, if not explicitly national publications, publications whose reach exceeded the geographical area in which they were published. ${ }^{134}$ Calculating their exact circulation is an impossible task; however, it is very likely

\footnotetext{
132 Parkinson and Griffith, Books in Māori. 1815-1900: Ngā Tānga Reo Māori (Auckland, Reed Publishing, 2004).

133 Parkinson and Griffith, Books in Māori.

${ }^{134}$ Paterson, Colonial Discourses, p.19.
} 
that niupepa were passed from hand to hand, sent from one person to another, read aloud to groups, and in all likelihood, circulated well past the date they had been superseded by subsequent editions.

The relative cheapness of niupepa also may have contributed to their popularity, in a similar fashion to the ubiquitous nature of cheap Englishlanguage newspapers. Niupepa were also many times cheaper than bound books, with a yearly subscription to Te Wananga niupepa costing 10 shillings yearly in $1875^{135}$, and a 1909 annual subscription of Te Pipiwharauroa only 5 shillings ${ }^{136}$. English-language newspapers of a similar vintage, however, could cost considerably more; 20 shillings per annum for the Southland Weekly Times ${ }^{137}$ in 1874, and 35 shillings for the Auckland Star in $1872 .{ }^{138}$ This is hardly surprising, as English-language newspapers were profit-driven, unlike niupepa, a point worth examining at a later date. Novels, however, were a different story. A colonial edition of the novel Kenelm Chillingly, for example, cost more than $8 \mathrm{~s}$ in 1873. ${ }^{139}$ Many reo Māori speakers lived in rural areas of the country or far from bookshops, and niupepa circulated through the postal system or passed informally from hand to hand around the country no doubt presented a more affordable and feasible form of reading material than books. The sheer fact of their relative affordability would also have made them more popular, while expensive books may have been limited to those relatively well-off, working in government departments or well-advanced in a cash economy. Even niupepa, however, were out of the reach of some, with niupepa themselves sometimes beseeching their subscribers to pay their fees, and going so far as to publish lists of the names of those who had done so and those who had not. ${ }^{140}$

A mismatch between the language most books were written in (English) and the language most Māori were literate in (reo Māori) was a further limiting factor in the availability of books and other texts to Māori. Books in reo Māori

\footnotetext{
${ }^{135}$ Te Wananga, Vol. 2 No. 7, 12 May 1875, p.1.

${ }^{136}$ Te Pipiwharauroa, No.141, December 1909, p.12.

137 Southland Times, 22 July 1874, p.2.

${ }^{138}$ Auckland Star, 16 August 1872, p.2.

${ }^{139}$ William Lyon, Wellington Independent, 5 July 1873, p.3.

140 Te Pipiwharauroa, No. 141, December 1909, p.11.
} 
were, unsurprisingly, a small share of the printed market. Paterson makes the pertinent point that 'the texts available to Māori were less extensive in number and scope than [those available] to many other societies' ${ }^{\prime 41}$. Many of the translated 'texts' available to Māori were alphanumeric tables, language guides, open letters, petitions and bills. The number of full texts published and disseminated in Reo Māori (excluding scriptural material) was very low ${ }^{142}$, and the majority of such texts in either language were authored in New Zealand. Novel translations into reo Māori were rare, and other works of classic and educational literature almost non-existent. In fact, until Pei te Hurinui Jones' translations of Shakespeare from 1945 only two long-form works, Robinson Crusoe (1852) and The Pilgrim's Progress (1854), appear to have been published as works of literature in their entirety (in 1852 and 1854) in Reo Māori. These were accompanied by a handful of short moral stories, and were governmentsponsored publications, part of an abortive campaign to translate works of literature into Reo Māori. The remainder of translated texts were either very short texts, for example poems and magazine articles, or selections from longer texts. Māori reading of imported texts, therefore, was often in small doses and selections, rather than entire texts.

Before the Native Schools Act 1867, reading in Mission and Village schools was effectively only taught effectively in reo Māori, ${ }^{143}$ and necessarily resulted in a population literate largely, if not entirely, in their own language. Māori readers of English, up until some time after the 1870s, are almost certainly the exception to the common rule. In addition to the reo Māori-specific literacy taught at formal schools, literacy was often transferred informally from one reo Māori-reader to another ${ }^{144}$, in a home and community rather than a formal educational context, or even at informal schools set up by literate exslaves and community members ${ }^{145}$. This almost certainly resulted in a Māori

\footnotetext{
${ }^{141}$ Lachy Paterson, 'Print Culture and the Collective Māori Consciousness', JNZL, No.28, Part 2, 2010, pp.105-129, p. 109.

142 Griffith and Parkinson, Books in Māori.

143 Paterson, Colonial Discourses, pp. 40-41.

144 Paterson, Colonial Discourses, p. 39.

145 Paterson, Colonial Discourses, p. 39.
} 
population in which the main language of literacy was reo Māori, and therefore, for whom most reading would have occurred in reo Māori. Some Māori, however, read in English in addition to or instead of reo Māori, from the beginning of Māori acquisition of literacy to the close of the century (and beyond). The young boys educated at a mission school in England in the 1830s provide an early example of Māori reading in English, as do boys at Samuel Marsden's school in Parramatta, Sydney. ${ }^{146}$ Numbers of Māori literate in English, of course, grew after the Education Act of 1876 shifted education policy's emphasis onto literacy and speaking in English, and, at the beginning of the twentieth century, a cohort of well-known figures, including Apirana Ngata, Reweti Kohere, and Golan Maaka, whose literary tastes are well-documented, read both in English and Māori, and accordingly were able to access a much greater range of literature. Several well-known book libraries held by the figures above and others included extensive collections of English books, and there were certainly more books available in New Zealand to those who could read in English.

Despite the explicit aim of settler institutions to communicate settler culture to Māori, very little reporting of Māori reading practice or literacy occurs in niupepa; however, despite this dearth of reporting, the existence of niupepa themselves demonstrates that there was an audience that could and did read them. Letters and articles to niupepa, however, provide snapshots of what was considered usual and unusual reading practices over the fifty-odd years in which niupepa were widespread. Te Karere o Poneke provides an obituary for a child whose brief four months at school were followed quickly by his death, however not before the youth had acquired literacy in reo Māori, and an eager interest in the English language and English books, which provided comfort and an expression of piety during his illness. The child, Ihaka Aperahama Rawhi, is presented as a behavioural exemplar in large part due to his eagerness to read, and particularly to read in English. ${ }^{147} \mathrm{~A}$ letter to the printer of Te Waka Maori o Niu Tireni in 1863 asks simply for a supply of 'pukapuka maori' and 'pukapuka

\footnotetext{
14630 April 1836, Missionary Register, No. 348, July 1839.

${ }^{147}$ Te Karere o Poneke, 31 December 1857, p.1.
} 
pakeha' to be sent - probably referring to newspapers (rather than books), in both English and Reo Māori, and hinting at a supply for a population with members literate in both (or either) Reo Māori and English, ${ }^{148}$ and pre-dating the Education Act of 1867. However, two articles in the same niupepa in 1875 and 1876 draw attention to English-language literacy as a curiosity, the first remarking on a second death of a young Māori student, Ripeka, literate in English ${ }^{149}$, and the second remarking how pleasing it is that '[Māori] skill in reading English, their knowledge of the doctrines of Christianity, their acquaintance with the maps and general knowledge... were pleasing proofs of the progress they were making"150. Māori literate in English were evidently no longer, by this point, an anomaly, but still worthy of note. By the turn of the century, however, Māori in the native schools system were being taught to read and write in English, and in 1901 an article in Te Pipiwharauroa considered the problem to be not so much that children were not learning to read in English, but that they were unmotivated to do so, and that it might be deleterious to their learning in other areas. ${ }^{151}$ It is evident that Māori readers who read in English did exist, and in sufficient numbers to be written about throughout the century. However, with the aforementioned practice among Māori groups of pupils teaching others outside formal European educational institutions, a Māori-owned informal literacy transfer system was well-developed before formal education, particularly the English-language literacy taught from 1867, took hold. Literacy in Reo Māori almost certainly remained a strong force at the end of the nineteenth century, and equally, many Māori who could not read in English could do so in Reo Māori. Niupepa, although diminished in number from their heyday in the 1850 s and 1860 s, provided reading material for and lasting traces of these Reo Māori readers.

\footnotetext{
${ }^{148}$ Te Waka Maori o Ahuriri, 25 July 1863, p.3.

149 Te Waka Maori o Niu Tireni, 9 March 1875, p.56. Trans. supplied by niupepa.

${ }^{150}$ Te Waka Maori o Niu Tireni, 25 January 1876, p.14. Trans. supplied by niupepa.

${ }^{151}$ He Kupu Whakamarama, 1 November 1901, p.3.
} 


\section{Māori Reading Practices}

Māori reading practice differed from the ideals of civilised reading encouraged by educators and commentators of the time in that it was often aloud, and often communal. According to contemporaneous reports, reading aloud and reading in groups appears to have been a favoured reading practice among Māori, particularly Māori reading niupepa. Paterson draws attention ${ }^{152}$ to the Reo Māori phrase 'korero pukapuka', meaning 'reading', and literally translated 'to talk books' as indicative of the way in which reading was thought of and practiced. Reading aloud, Paterson argues, would have been the accepted norm in Māori communities.

Across Europe at this time, students were taught to read aloud, rather than silently, ${ }^{153}$ and Mission and Native Schools were no different. ${ }^{154}$ The Reo Māori-literate reader of the nineteenth century was firstly an oral reader, sounding out text and aurally reproducing its content in real time as he or she read. This fact in itself has several implications. The first of these was that by learning reading as reading aloud, rather than reading silently, Māori were introduced (and introduced each other) to a practice that was unmistakably new and strange. However, this process had notable similarities to already existing oral culture, as reading aloud communally, particularly coupled with discussion of the text, mimicked the conventions of oral debate and oral literature. The content of the text was prescribed, whereas while history and whakapapa passed down orally changed in accordance with their context, they also included set content. The content was moreover accessed from an external source (a wad of paper or bound book) rather than from the speaker's memory and the communal memory of the group. The content of either oral literature or written literature alike was then given embodiment through becoming a string of spoken words, exhaled from the body and blurring the distinction between reader and speaker. Ngata refers to the oral communication of printed texts as 'closer... to

\footnotetext{
152 Paterson, Colonial Discourses, p.38.

153 Reinhard Wittman, p.290.

154 D. F. McKenzie, Oral Culture, p.17.
} 
what they had been accustomed to; it was nearer to the old-time narrative of adept raconteurs or of poetical and priestly reciters.' ${ }^{155}$

The second implication is that the act of reading, in a culture of reading aloud, was by no means always a private act. Again, like oral storytelling or even like marae oratory and debate, reading aloud often seamlessly became reading to others, or reading to a group. It was common for niupepa to be 'shared and consumed multiple times, read out at meetings and discussed publically'. ${ }^{156}$ In a communal culture built around whānau ties, and often living in close quarters with relations, this can have been often no less than inevitable, whether the reader him- or herself wished for privacy or not. Walter Brodie, remarking in 1845 about the reception of Te Karere o Niu Tireni in the early 1840s, cites evidence of Māori reading aloud to a group:

One native is generally selected to read the news aloud... after the reader has promulgated the contents, the different natives, according to their rank, stand up and argue the different points contained; which being done, they retire home, and answer the different letters by writing to the editor. ${ }^{157}$

Newspapers themselves, self-referential to the last, carried many reports of Māori reading in groups. The masthead of 'Ko Aotearoa' (otherwise known as 'The Māori Recorder') depicted a Māori group being read to in its masthead. The activity depicted is not a solitary one; on the contrary, a group of Māori figures clusters in front of a whare listening avidly to a Māori man in European dress, reading aloud from a bound and printed volume. ${ }^{158}$ The communal nature of the setting is unmistakable.

However, not only was Mãori reading practice adapted specifically for the communities it served, it also became a tool, both intentionally and nonintentionally, in fostering a sense of community between disparate settlements

\footnotetext{
155 Apirana Ngata, 'The Maori and printed Matter', in R. A. McKay (ed.) History of Printing in New Zealand 1830-1940 (Wellington: Wellington Club of Printing House Craftsmen, 1940), p.48.

156 Paterson, 'Print Culture and the Collective Māori Consciousness', p. 2.

${ }^{157}$ Walter Brodie, Remarks on the Past and present State of New Zealand: Its Government, Capabilities, and Prospects (London, London Whittaker and Co, 1845), p. 110.

158 Lachy Paterson, 'Visual Identity in Niupepa Māori Nameplates and Title-pages: From traditional to Aspirational', Script \& Print, Vol.38, no.2, 2014, pp. 67-79, p.71.
} 
and groups. This was the avowed intention of some publications, such as Huia Tangata Kotahi, a niupepa whose purpose, to foster connection between different iwi, was advocated in its very title, 'Bringing people together'159. The various niupepa and other publications were very aware of their purpose in forging connections and sharing news between Māori communities in different parts of the country. Lachy Paterson has written extensively on the links between niupepa formation and reading, and a heightened sense of community. Paterson contends that a sense of Māori collective identity, rather than hapū or iwi allegiance, was a reaction to European settlement, which, in introducing an 'other' to Māori society, created a new sense of distinction between Māori and Pākehā and, in correlation to this, a developing sense of 'Māori' cohesion. Paterson writes that 'The development of a Māori "national" or collective consciousness... was a response to Pākehā settlement ...and, as with emerging nationalisms in other societies, this was shaped by print culture, in particular newspapers.' ${ }^{160}$ Although Māori possessed remembered links to the pacific, and a conception of themselves as distinct, social organisation was based around connected iwi-based clusters. Māori national consciousness certainly did begin to solidify after the arrival of Europeans, with the Declaration of Independence 1835 and Kohimarama Council two politically-motivated early examples (in the north of the country) of gestures at cohesive action and nation-forming. More fundamentally, the concept of two separate races, Māori and Pākehā, was common currency during the niupepa era. This was perhaps unsurprising, as many early niupepa were run and printed by Pākehā. However, later niupepa with high levels of Māori involvement also draw this distinction. Māori reading was actively promoted by influential figures such as Ngata and Reweti Kohere as well as by Pākehā educators and policy-makers, and a widespread population reading the same texts via the niupepa could not but create a sense of community engagement. The form of niupepa in particular, encouraging contributions and debate across issues, was particularly suited to this. Māori who wrote in to niupepa, in particular, were particularly aware of a wider

\footnotetext{
${ }^{159}$ Huia Tangata Kotahi, masthead

${ }^{160}$ Paterson, 'Print Culture and the Collective Māori Consciousness', p.1.
} 
community accessing their printed words, sharing and consuming the same text in what functioned in many ways as a community forum. ${ }^{161}$

Paterson quotes Benedict Anderson's 'Imagined Communities' concept, stating that 'the very act of reading print, say a newspaper, allowed an individual to imagine him or herself as part of a larger population, all reading at the same time. People became more aware of commonalities... whilst all (the community's) members effectively remained strangers. ${ }^{162}$ However according to Ballantyne ${ }^{163}$, between 1850 and 1900 no New Zealand (English language) newspaper could claim to be national. 'Māori-language papers, in contrast... looked out beyond the local to wider Māori issues' ${ }^{164}$ Nor did Māori niupepa confine themselves to 'Māori issues', with many translating and reprinting news of the wider world, including international conflicts, alongside reports of meetings and petitions at a local or national level. ${ }^{165}$ The agenda of niupepa, however, was rarely profitmaking, but rather more often 'to change Māori thought and behaviour'. Niupepa were not all, of course, solely motivated by modifying their readers' behaviour. Entertainment, dissemination of information, and soliciting news and information from readers were also important motives. However, it cannot be denied that niupepa were (implicitly or explicitly) a means by which cultural change came about, and, particularly, changed the way in which literate Māori conceived community. Moreover, they were highly effective means of communication. Reading, then, was a very efficient, cheap method of spreading ideas and prescriptions of how commerce, civilisation and religion should be adopted by Māori. The act of reading as a marker of civilised behaviour was not the end goal; rather it was a delivery method designed to subvert a culture to whatever ends the niupepa's backers wished. Reading both symbolised and strengthened cultural change, but it was only one part of the changes publishers hoped would be wrought through it. Nevertheless, the behaviour of reading

\footnotetext{
${ }^{161}$ Paterson, 'Print Culture and the Collective Māori Consciousness', p.1.

162 Paterson, 'Print Culture and the Collective Māori Consciousness', p.1.

163 Tony Ballantyne, 'Talking, Listening, Writing, Reading: Communication and Colonalism', The Allan Martin Lecture, (Canberra, ANU, 2009), p.22.

${ }^{164}$ Paterson, 'Print Culture and the Collective Māori Consciousness', p.2.

165 Te Waka Māori o Ahuriri, Vol.6, no.15, 7 October 1870, p.1.
} 
itself inevitably changed as print became more and more useful effective in community-building, both in those niupepa who took this as an explicit aim, and those that did not, by means of their nature: reflecting news of the population back to them, and publishing their further developments, cyclically. Maori were, Paterson points out, 'aware of the wider reading community', engaging by writing 'many letters to newspapers with the express purpose of reaching as wide an audience as possible ${ }^{166} \mathrm{~A}$ notable example of this can be found in Paratene Ngata's letter to the Anglican niupepa, Te Pipiwharauroa, in 1911. Ngata greets the editors of the paper, and asks that 'If this notice pleases Te Pipi, please carry it over the wide reach of our bird, ${ }^{167}$ so it might be seen by our good friends in distant places' (emphasis mine). ${ }^{168}$ Here, Ngata explicitly expresses his wish and expectation that by publishing his own words in a niupepa, he will be able to reach and affect far-flung members of the niupepa-reading 'community'. Although Ngata's salutation is an aside only, his letter's almost casual nature points to his acceptance of the medium as a form of communication. Through the durable nature of printed words, he deliberately uses the niupepa medium to foster community across lines of distance and time that had previously been barriers.

\section{Disapproval of Māori reading practice}

While criticism of reading in the New Zealand mainstream focussed on urging the common reader to read seriously, deliberately and in pursuit of information, criticism of Māori reading had a different focus. Māori, in general, embraced reading, embraced niupepa as a useful form of communication and information, and developed a reading practice well-integrated into existing traditions of communication. Pākehā-run niupepa, however, found cause for

\footnotetext{
166 Paterson, 'Print Culture and the Collective Māori Consciousness', p.2.

${ }^{167}$ Niupepa were commonly metaphorically referred to as birds, e.g. Te Pipiwharauroa, Te Pìhoihoi Mokemoko, Te Hokioi, Te Kopara.

168 Paratene Ngata, Te Pipiwharauroa, in Te Ohorere and Wiremu Kaa (eds), Ngā Kōrero o Reweti Kōhere $m \bar{a}$ (Wellington, Victoria University Press, 1994), p. 166. Trans. FDB.
} 
concern in Māori reading practice (rather than content), particularly the 'uncivilised' and unprofitable nature of communal reading.

In part, this was because many Pākehā-run niupepa had a civilising mission, often couched as a fostering of understanding between races, at their heart. Te Karere o Nui Tireni states that its purpose is: 'so that the Maori people would come to know the ways and customs of the Pakeha and the Pakeha would also come to know the customs of the Maori people. ${ }^{169}$ Te Waka Māori o Ahuriri, a pro-government niupepa, also aimed to 'repair the rift between Pakeha and Maori. ...Nowadays the majority of Pakeha are quite ignorant of Maori views, and the Māori too are quite ignorant of Pakeha views.' Even niupepa which expressly forbade political discussion in their pages displayed an interest in communicating settler custom to Māori (and, to a lesser extent, vice versa). Te Karere Māori, which admitted only 'articles of general interest and value'170 included a selection of 'articles on law, banking and other British customs... the origin of the wealth of English people, agricultural and horticultural societies, how to till the fields, farm the land, milk cows', and "articles on the customs and history of the 'aborigines of New Zealand"'171. In contrast, later, more Māoricontrolled niupepa such as Te Puke Ki Hikurangi and Te Pipiwharauroa were concerned less with cultural integration, and more with reporting on Māori institutions (e.g. the Diocese of Waiapu and the Kotahitanga Parliament) and, as communicated in Te Puke's mission statement, reporting 'the news of the world, which our ears listen for and our minds question in vain amongst ourselves... Friends, I [Te Puke] am here to provide the answers.' ${ }^{172}$ Pākehā-run niupepa, then, had an interest in explaining and impressing the importance of settler customs on Māori, and used the niupepa as a medium through which to

\footnotetext{
${ }^{169}$ Te Karere o Nui Tireni, 1 January 1842, p.1.

170 'Commentary on Te Karere Maori, 1849-1854', Niupepa Māori, URL http://www.nzdl.org/gsdlmod?gg=text\&e=d-00000-00---off-0niupepa--00-0----0-10-0---0--0direct-10---4-------0-11--11-en-50---20-about---00-0-1-00-0--4----0-0-11-10-0utfzz-8$00 \& a=d \& c=$ niupepa\&cl=CL1.3\&d=02commentary, accessed 28 January 2015. 171 --------, 'Commentary on Te Karere Maori, 1849-1854', Niupepa Māori, accessed 28 January 2015.

172 -------, 'Commentary on Te Puke ki Hikurangi', Niupepa Māori, URL http://www.nzdl.org/gsdlmod?gg=text\&e=d-00000-00---off-0niupepa--00-0----0-10-0---0--Odirect-10---4-------0-11--11-en-50---20-about---00-0-1-00-0--4----0-0-11-10-0utfZz-8-

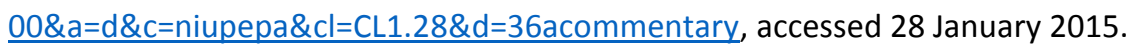


disseminate this content. The dismay expressed by some niupepa towards the oral reading culture which grew up may well have been motivated by this same urge to have things done in a civilised fashion, including the reading which made the communication possible.

Financial solvency was another, self-interested reason for niupepa to discourage oral, communal reading. Although some niupepa run by the settler government received funding from the same source, all, including the funded papers, required some level of fundraising through reader subscriptions and niupepa sales, and communal reading threatened these sales considerably. Te Tiupiri (The Jubilee), a Reo Māori and English niupepa printed in Whanganui, was considerably concerned about communal reading, and printed several pieces describing this unsatisfactory practice and exhorting its Māori readers to desist, the first stating (in English)

We would remind our subscribers that it is not well to read out the news of the paper to all and sundry, as that is one evil which may befal [sic] our newspaper and prevent others from subscribing, but let us act as the pakeha does... and let each man get a paper for himself for his own enlightenment. ${ }^{173}$

Perhaps it is significant that Te Tiupiri published this piece in English first, with a Māori translation held over until the next week's issue. This was not standard practice for the niupepa, which aimed at both an English-language and Reo Māori-speaking population, and generally published its bilingual articles (the majority) in parallel translation. As a publication, Te Tiupiri may have been more concerned with being seen by similarly concerned peers and English-speaking readers to chastise its Reo Māori readers than actually carrying out said chastisement. An alternative explanation would be that, like many niupepa, articles were composed in English and translated into Reo Māori, and a translation was not procured before the niupepa went to press. However, the

${ }^{173}$ Te Tiupiri, 4 January 1898, pp.5-6. 
language in which a message purportedly directed towards Māori was communicated may well be indicative of the niupepa's priorities.

A letter sent in to the same niupepa later in the year complained at length that:

"one error of the Māori race is that a learned or respected man will acquire a paper, and will go and read it amidst a crowd, therefore the whole crowd hears the news... the people become blasé about taking a paper, saying "I've read the paper, so I won't take one." This will eventually be a road to destruction for this paper... don't leave it for news to be spread by mouth, rather support the paper. But support it with funds. ${ }^{174}$

It appears clear that Te Tiupiri was concerned about the effects on its revenue of newspapers being shared among groups. The business imperatives of subscribers purchasing, rather than sharing, a commercially produced paper, were indeed a factor worthy of consideration. Te Tiupiri may have been right to worry about their future financing, as many Reo Māori newspapers had foundered for want of funding over the previous fifty years. A niupepa's survival was dependent upon the reading habits of its customers complying with the commercial equation of individualised purchase of a commodity. Almost all niupepa, in fact, struggled with financial difficulties. Te Karere Maori, Te Karere o Niu Tireni, Te Karere o Poneke, and Te Waka Maori o Ahuriri, were just a few of the niupepa receiving support from the government ${ }^{175}$, ranging from small lump sums to ongoing government monies. Others, however, struggled to remain financially solvent. Although turbulent circumstances and instability also contributed to the decline of niupepa, many niupepa folded for lack of funds, some very quickly. ${ }^{176}$ Others survived for a while on inadequate reader subscriptions. Only a handful of niupepa survived by the time Te Tiupiri made its debut, and that publication took an interesting approach to the problem of coaxing money from their subscribers, conflating readers sharing their niupepa

\footnotetext{
${ }^{174}$ Te Tiupiri, 11 January 1898, p.4.

175 Paterson, Colonial Discourses, pp.19-13.

176 Paterson, Colonial Discourses, 23.
} 
with their moral state. Not once does the niupepa itself plainly state that passing niupepa around will lead to a precarious financial position. Instead, it draws vague connections between negative outcomes for the newspaper, claiming, as seen above, "that is one evil that may befall our newspaper"177 and "it is not well to read out the news of the paper to all and sundry"178, but that the reader should instead "act as the Pākehā does"179 and "get a paper... for his own enlightenment". ${ }^{180}$ The niupepa therefore makes a link directly from their prescribed reading practice to a moral good - or more precisely, an immoral evil.

Earlier in the century, Napier niupepa Te Waka Māori o Ahuriri, later Te Waka Maori o Niu Tireni, had taken a novel approach to the ostensible problem of communal reading practice by offering communal subscriptions, rather than insisting subscribers pay individually, and then refrain from sharing their bounty. Te Waka Maori suggested that "Maori pa collect five pounds each in return for [a] communal subscription"181. Although Te Waka Maori also likely received government monies, this approach both legitimised and monetised reading as part of a communal life, rather than attempting to individualise both reading and a wider life, and chastise any deviation, as Te Tiupiri would do forty years later. In this way, reading practice and niupepa reactions to it mirrored the trajectory of other prescriptions for cultural change among Māori.

In a context in which reading in New Zealand was becoming more and more popular, and opportunities to do so becoming easier and more frequent, Māori were not left out. Reading was enthusiastically practised by many Māori, and transmitted outside formal educational systems from one reader to another, new-born reader. This reading was largely in Reo Māori, although a sizable group, probably a minority that grew as the century went on, read in English or in both languages. Reo Māori vocabulary at the beginning of this reading revolution did not differentiate between different types of print, e.g. between a book, letter,

\footnotetext{
177 Te Tiupiri, 4 January 1898, pp.5-6.

178 Te Tiupiri, 4 January 1898, pp.5-6.

179 Te Tiupiri, 4 January 1898, pp.5-6.

180 Te Tiupiri, 4 January 1898, pp.5-6.

${ }^{181}$ Te Waka Maori o Ahuriri, 13 June 1863, p. 2.
} 
pamphlet or newspaper, and the types of content contained in each was to some extent interchangeable. Readers, however, were increasingly aware of the different opportunities offered by different types of print. Books were popular, and niupepa appeared to have a high circulation. However, official anxiety about the content and manner in which all New Zealanders read was certainly present, and Māori were not exempted from this. While Pākehā settlers were urged to read serious works and to read intently, ideas bound up with a modern, educated ideal of life, criticism of Māori reading focussed more on practice deemed, by editors in the main, unacceptable. Māori reading practice was, however, an adaptation and blend of established traditions of debate and communication, with the new technology and skills of print and reading, and suited its purpose well for the communities that practiced it. The common practices of reading aloud, or reading in groups, ${ }^{182}$ though fitted for community needs, were later decried as uncivilised, not befitting intelligent men, and, though less explicitly stated, uneconomic. At the turn of the century, a low point for the Māori population in terms of both numbers and cultural expression, this enthusiasm for reading, and reading in Reo Māori, may have been on the wane as reading in English became more widely practiced, and reading began to be seen as a distraction from more practical subsistence matters. The reasons why Māori should read became a matter of much debate.

182 The New Zealand Spectator, p.2. 


\section{Why Māori Read}

Over the course of the nineteenth century, a time when Māori lost most of their sovereignty, reading was a contentious subject. Some saw reading as a pragmatic skill by which Māori readers could advance their own knowledge and fortunes. Another view, particularly expressed towards the close of the nineteenth century, was that reading was intrinsically a worthwhile pursuit, and a deep understanding of a text, particularly texts imported from offshore, was an end in itself. Others, however, viewed reading with deep suspicion. Reading was seen by some as a waste of time or, in a more sinister light, as one of the main methods by which Pākehā practices and education were communicated to children, an instrument of Pākehā domination over Māori practices. Over the half-century from 1842, from the date the first niupepa were published, to the early years of the twentieth century, reading became integrated into many Māori lives as both a useful skill and as an enthusiastically engaged-in pastime. Early niupepa, books and other publications were almost all written in reo Māori. Reading in English became more widely taught with education reforms from the 1860s, but some still read in reo Māori, for a range of reasons. Attitudes to reading changed, developed and diversified as generations who had grown up literate developed an experience of its benefits and pitfalls. Precedents for the 'why' of reading were also examined, discarded or retained. Reasons to read, or not to read, were the subject of some discussion in the niupepa, suggesting that the reading that did take place was contested, either for quantity or quality.

Reading as a useful tool in the pursuit of knowledge remained a common thread in the discourse about reading throughout the half-century. Other motivations, however, included reading as moral and personal good, reading as distraction, and reading for self-identification and became part of the debate about reading, and reading translated texts. At the same time, publishing ensured a range of Maori texts were recorded and disseminated to readers. As literacy became more widespread, so too the range of translated texts available to readers grew. 
According to various niupepa, by the close of the nineteenth century, reading was less commonly seen as a useful tool. Some cited young Māori leaving school without a shred of interest in reading or continuing literacy, ${ }^{183}$ as seen in a 1901 article in Te Pipiwharauroa which lamented that 'There are many children who return from Te Aute and Hukarere ${ }^{184}$ shying away from reading. This is a very regrettable practice. ${ }^{\prime 185}$ Bradford Haami recalls how kaumātua of the 1940s and 1950s, remembering their own childhoods of the turn of the century, would hide or burn their grandchildren's schoolbooks, 'believing them to be a Pākehā tool teaching Pākehā views' ${ }^{186}$ According to others, it was the only method by which young Māori would be able to make their way through the world.

At the turn of the century, however, some niupepa argued that reading could come to represent a means of Māori self-determination. Te Pipiwharauroa and its preceding and succeeding Anglican niupepa were written by highly literate, politically influential Te Aute College alumni such as Apirana Ngata, Reweti Kohere, Sir Peter Buck, and James Carrol, who very much subscribed to this view. They were views echoed by Te Puke Ki Hikurangi, a Wairarapa niupepa written largely from a Kotahitanga movement viewpoint. The contemporaneous ideals presented in these niupepa encouraged using whatever tools of the Pākehā came to hand in order to build a strong Māori culture. This formed a framework in which Māori niupepa contributors discussed the value of reading as a means of learning, building up useful knowledge, and gaining selfknowledge and fulfilment. The highly literate Reweti Kohere, in particular, was an advocate for lifelong and purposeful reading.

\section{Literacy rates, entertainment and information}

Māori motivation for reading in the mid-nineteenth century has long been the subject of debate. It is clear that some Māori enthusiastically embraced

\footnotetext{
${ }^{183}$ A development which may be linked to changes in the education of Māori children and how literacy was taught, and associated suppression of reo maori.

184 Boys' and Girls' Anglican Māori Colleges, respectively.

185 Te Mahara, 'Te Korero Pukapuka', in Te Pipiwharauroa, No.45, 1 November 1901, pp.2-3.

${ }^{186}$ Bradford Haami, Pūtea Whakairo, p.9.
} 
literacy as early as the 1830s, and that literacy continued to spread throughout the 1840 s. The extent of this spread has been the subject of some controversy, and is still a live issue to which D. F. McKenzie, Buddy Mikaere and Lyndsay Head, and Lachy Paterson all make notable contributions. ${ }^{187}$ However, despite differences of interpretation among researchers as to degree, even the most conservative estimates agree that a significant percentage of Māori were in fact literate, and did continue to read, and spread literacy amongst themselves, throughout the rest of the $19^{\text {th }}$ century.

The question of why reading became popular is, of course, just as difficult to examine as the question of whether it did so. Mikaere and Head, in their 1988 article "Was $19^{\text {th }}$ Century Maori Society Literate", cite iwi proceedings from this period as evidence that writing and reading were seen as a valuable tool by which to disseminate knowledge of Māori affairs to a wide audience. In particular, Mikaere and Head note that 'when Tawhiao was king, speeches were ... written down and circulated, as were the statements of visiting leaders such as Te Whiti and Te Kooti'. ${ }^{188}$ Mikaere and Head state that unlike speeches on the paepae today, speeches on Kingitanga marae represented the sharp end of business in the 1850s and 1860s, and for these to be routinely recorded and circulated in writing suggests strongly that literacy was both widespread and widely acceptable. The obvious benefits of being able to keep written records of proceedings indicate that Māori in the Kingitanga, as well as in the northern North Island, had integrated reading seamlessly into daily life.

A well-canvassed reason for Māori to take up reading was as a matter of practical information seeking, and it was not long after the beginning of Māori literacy that readers were able to take up articles giving useful advice, which began to appear frequently in niupepa. The niupepa often posted explanations of their editorial selections and their speculations on what would draw Māori to

\footnotetext{
187 McKenzie, D. F. McKenzie, Oral Culture, Literacy \& Print in early New Zealand: the Treaty of Waitangi, Wellington, 1985, Lyndsay Head and Buddy Mikaere, 'Was $19^{\text {th }}$ century Maori Society Literate?', Archifacts, Conference Papers, Vol.2, 1988, pp.17-20, and Lachy Paterson, Colonial Discourses: Niupepa Māori 1855-1863 (Dunedin: Otago University Press, 2006).

188 Mikaere and Head, 1988, p.20.
} 
read their niupepa. This provides us with an insight more into expectations than real reports of readers' motivations, but still furnishes a glimpse of the reading climate. Te Karere Maori, one of the earliest niupepa, printed in an early edition (in 1849) its statement of intent in English and reo Māori parallel translation, reading (in English):

Kind Māori Friends, You, for whose instruction and amusement the Governor first designed this paper - in our anxiety to please and instruct you, we have made many inquiries as to your particular tastes, and with regard to the description of reading you would be likely to prefer; in order that we might not only be able to improve your minds, but to impart to them the same pleasures that are so eagerly sought after by the educated of all nations. For this purpose, we have supplied you with various pieces of information... in short, nothing that we ourselves or the many kindly friends, who assist us, have imagined you would like to know, or which we deemed it of service to impart, but what has been placed within your reach. ${ }^{189}$

In this particular extract, the government-sponsored niupepa introduces its friendly mission statement of 'instruction and amusement'. It also, however, positions itself as a kind of 'soft' propaganda, instructing Māori readers on what was useful knowledge, and positioning its own, Eurocentric choices about whwhich information was useful or 'correct' for their readers.

The Pākehā, government-sponsored newspaper editors determined, from their many enquiries, that Māori readers wished both to be entertained, and to be educated. While a perceived wish to be educated and entertained is explicitly expressed in some niupepa, and implicitly adhered to in others, the root motive of both kinds of readeris assumed to be a wish to become more like the educated of all nations'; that is, more like Pākehā. Given the wider historical context, this is unlikely to have been an accurate reflection of most Māori's

${ }^{189}$ Te Karere Maori, Vol.1, No.12, 7 June 1849, p.1. 
motivations in reading. However, it is very clear that many Māori readers were in fact reading in order to inform themselves. The excerpt from Te Karere Maori above quite plainly takes this for granted. The editors state 'we have supplied you with various pieces of information... [which we] imagined you would like to know, or which we deemed it of service to impart ${ }^{\prime 190}$. Other niupepa throughout the second half of the nineteenth century echoed the sentiment that information was their goal, with articles on beekeeping ${ }^{191}$, English history ${ }^{192}$, and, to take an example from the Karere Maori, the history and geography of Australia. ${ }^{193}$

Other government sources however, appealed to a perceived fear in their readers. Te Karere o Poneke, another government-controlled niupepa, issued an extremely blunt-edged dictum to its readers: that to be unlettered was to be ignorant. This niupepa equated literacy with schooling, with knowledge, and with an eventual path out of the 'ignorant ways of before'. 194 'Send the children to school, to learn to... read books; that is, Pakeha books, as these books will show the Maori Pakeha ways, since Pakeha books are written by some of the most learned men in the world. ${ }^{195}$ In another edition, the same niupepa stated that it was only through reading books and writing that Pākehā children achieved greatness, and urged Māori to take up the same opportunities by sending their children to school, and also urged kaumātua who wished to 'enter into Pakeha traditions' to take up reading also. ${ }^{196}$ Government sources, plainly, were determined that Māori should find civilisation through reading - a stance very much in line with broader government policy of the time. Reading, introduced by missionaries in order to educate Māori about the Christian scriptures ${ }^{197}$, easily translated, in colonial policy, to a policy of 'racial amalgamation' through literacy

\footnotetext{
190 Ibid.

191 'Te Ngaro Hanga Honi', Te Karere Maori, Vol.1, No.25, 6 December 1849, p.4.

192 'Nga Kahika', in Te Karere Maori, Vol.1, No.24, 22 November 1849, p.4.

193 Te Karere Maori, Vol.1, No.2, 19 January 1849.

${ }^{194}$ Te karere o Poneke, Vol.1, No.25, 26 April 1858, p.3.

195 Ibid.

196 Te Karere o Poneke, Vol.1, No.37, 26 July 1858, p.4.

197 Bradford Haami, 'Tā Te Ao Māori', p.169.
} 
and education ${ }^{198}$, with English culture and mores communicated through print and enforced through village and native schools.

Māori sources, however, endorsed the opportunity for knowledge afforded by the spread of reading. The very existence of a multitude of writings in reo Māori are testimony of widespread reading literacy. Individual texts are witness to an uptake of reading, from Tui, ${ }^{199}$ who said as early as 1818 , that 'he [Mr. Eyton, Tui's teacher] give me good book he tell me better... speak to my countrymen and learn him to read book'200, to 'written minutes, reports, letters, petitions, transactions, voting polls... and other documents' ${ }^{201}$ from land court proceedings, as the processes of the Native Land Court 'brought forth a prodigious volume of Māori historical narratives' ${ }^{202}$

Even these early sources, however, provided readers not only with information deemed useful, but also with light entertainment. In appealing to readers seeking entertainment, the Pākehā editors of Te Karere o Poneke state that:

... We shall also present you with some tales of what, in Europe, is called imaginative literature, that is, stories so true to nature, that the circumstances, although not occurring to the persons described in the tales, may, and have, again and again, occurred to others. ... We hope you may find an effectual means of letting us know what you think of [our articles]..$^{203}$

In a later edition they quote a favourable reception to their publication of such snippets, largely light animal fables:

\footnotetext{
198 Ross Calman, 'Māori education - mātauranga - Missionaries and the early colonial period', Te Ara - the Encyclopedia of New Zealand, updated 13-Jul-12, URL: http://www.TeAra.govt.nz/en/maori-education-matauranga/page-2

${ }^{199}$ Also spelled 'Tuai'.

200 Haami, Tā te Āo Māori, p.170.

${ }^{201}$ Haami, 'Tā te Āo Māori', p.178

202 Haami, 'Tā te Āo Māori', p.177.

${ }^{203}$ Te Karere Maori, Vol.1, No.12, 7 June 1849, p.1.
} 
... We are tempted to place this tale [Androcles and the Lion] before you, because we have been told that the anecdotes of the Canary bird, the Wounded Fish, and The Dog and the Calf, have afforded you much gratification. ${ }^{204}$

Animal fables, very popular in the early niupepa, continued to appear throughout the 1840 s and 1850 s. Fables as a literary form are both entertaining and designed to contain a (usually thinly-disguised) moral. The versions presented to readers of reo Māori niupepa often capitalised on this, elaborating on the applications of the fable and even explicitly linking it to aspects of Māori life, for example, an early edition of Te Karere Māori included the instruction, attached to a translation of 'The Lion and the Mouse', a fable illustrating benefits of a beneficent kindness from rulers to subjects, to 'be kind to their slaves, to their children, and to strangers' ${ }^{205}$ Despite early popularity, however, fables do not appear visibly in the niupepa of the 1860 s or from the 1880 s onwards, and perhaps fell from favour as hymns and ecclesiastical stories became more popular. While, as discussed above, some Pākehā translators and commentators speculated on Māori readers' relative tastes for fiction and non-fiction, both of these were represented throughout the era of widespread niupepa readership, and the distinction may have been of more concern to the Pākehā editors and printers who attempted to explain these concepts to their readers than to the readers themselves. It seems unlikely that Māori readers, who after all had a rich traditional heritage of myth and story of their own, would have been opposed to allegorical or fictional texts. Poetry, allegory and amusing tales all shared the pages of the niupepa press throughout the second half of the century, and there is no suggestion that they were not read and enjoyed.

\section{A changing context}

As the century progressed, the reading context changed. It's evident from the primary sources cited above that government-backed publications were certainly pushing the idea that reading was part of an essential set of Pākehā

\footnotetext{
204 'Anorokiri me te Raiona', Te Karere Maori, Vol.1, No.12, 7 June 1849, p.1.

205 'Ko te raiona me te kiore', in Te Karere Māori, Vol.1, No.15, 19 July 1849, p.4.
} 
skills, and moreover a method by which Māori readers could become more proficient in the Pākehā world and knowledge. At this point in the century (1858) although wars over land alienation had been fought in Northland, Whanganui and Wellington, Māori still held a fair degree of sovereignty over their own tribal territories and means of production and living conditions. Despite this, government publications had avowed intentions of 'civilising' Māori into European habits. Te Karere Maori explains in this extended advertisement for Grey's savings banks that its writers 'visit your native villages, and expect to find you progressing in civilisation', but are disappointed, and goes on to offer a list of suggestions as to how civilisation can be achieved. 206

In this context, this points to a disjuncture between the aims of the government niupepa (i.e. to civilise Māori into a European society) and of Māori readers (i.e. to strengthen and expand their own cultural and commercial interests by making judicious use of new resources, in this case, reading). As schooling for Māori children transitioned entirely to the English language, ${ }^{207}$ land wars progressed and Māori iwi steadily lost more land, reading became a point of tension in discourse in the niupepa. A complicating factor in Māori motivation for reading was the educational context. Since the 1867 Education Act, Māori children enrolled in formal education (which became compulsory in $1894^{208}$ ) had been at first encouraged, and then compelled, to speak and read only in the English language at school. This meant that, as far as reading within education was concerned, the Māori language was not represented, and reading in school became a tool for propagating Eurocentric ideas. Reading in school could no longerpresent Māori views to Māori children in their own language.

In the latter part of the nineteenth century and the very beginning of the twentieth, the value of reading (or lack thereof) was a topic of much debate, notably in the reo maori press, and in particular, in the Anglican niupepa, He

\footnotetext{
${ }^{206}$ Te Karere Māori, Vol.1, No.15, 19 September 1849, p.4.

207 Ross Calman, URL http://www.teara.govt.nz/en/maori-education-matauranga/page-3.

${ }^{208}$ Ross Calman. 'Māori education - mātauranga - The native schools system, 1867 to 1969', Te Ara - the Encyclopedia of New Zealand, updated 13-Jul-12, URL: http://www.TeAra.govt.nz/en/maori-education-matauranga/page-3 Te Ara http://www.teara.govt.nz/en/maori-education-matauranga/page-3.
} 
Kupu Whakamarama, Te Pipiwharauroa and Te Toa Takitini. Indeed, some arguments around reading at the beginning of the twentieth century were very much the same as those debated in the 1850s. In particular, writers in niupepa continued to urge reading as a method of gaining useful information. Whereas in the 1850 s government agents had urged Māori to begin to read, by the early 1900s Māori-produced publications had taken up this role. This is perhaps the result of a much more robust diversity of Māori voices in the niupepa, giving their own opinions and debating ideas about reading. While government agencies used reading to attempt to guide and shape Māori communities' behaviour, Māori groups also used printing and a fluently reading public to foster their own ends. Te Pipiwharauroa in particular was firm that reading was a valuable skill and method of learning.

It is important to note that reading was also seen in some quarters as a waste of time, as it distracted from necessary chores. How, or whether, education and leisure through reading should compete for time with manual education, manual work and commitments to the community was a subject under discussion in Te Pipiwharauroa. ${ }^{209}$ The argument was, in some aspects, compelling. Contemporary official views of Māori scholarship were that it ought not to be attempted ${ }^{210}$, and education for Māori boys and girls focussed heavily on hygiene and manual labour tasks. Moreover, in a world in which many Māori did not gain an opportunity to benefit financially or socially from the study of literature, reading could have been seen as an unattainable luxury. It is evident from the existence of this piece, contemporary with others discussed in this chapter, that the value of reading at all, let alone reading to gain knowledge from other cultures' writings, was very much under debate.

The Anglican niupepa at the turn of the century in particular were very concerned that Māori children be able to move fluently in Pākehā circles, and saw English fluency and literacy as a prerequisite for this. However, there are

\footnotetext{
209 Te Mahara, 'Te Korero Pukapuka', in Te Pipiwharauroa, No. 45, November 1901, pp.2-3.

210 Henry Taylor, in Appendices to the Journals of the House of Representatives, 1862, A-51, p. 38.
} 
some further indications that English literacy was seen as desirable in helping Māori children become better at agricultural occupations, at farming and shearing, and benefitting from keeping their own accounts and paperwork. A letter in the Kingitanga niupepa Te Puke ki Hikurangi, published in 1899, excitedly lays out a new method of increasing egg gain from laying hens and its possible applications for increasing Māori wealth. The anonymous letter-writer points out that "My friends, if this knowledge will lift up our elders, where is the harm in it... the Pākehā gain a livelihood from this work, but if young men and women learn this, and know also to read Pākehā books and speak their language, they can teach their elders; these children emerging from the school system are a treasure... so rather than keeping this knowledge to yourselves, teach it to the elders, ... that by this a small group will flourish." 211 The ability to read and write is here seen in the context of 'Pākehā knowledge'. A second letter in the same issue points out that, if Māori children want to achieve in a professional capacity, reading and literacy is their path towards such achievement. ${ }^{212}$ This knowledge is presented as a desirable thing, as a means to a better quality of life and wealth. Reading, writing and speaking English are presented as integral parts of this equation.

However, the fact that this article was written speaks to the probability that the niupepa itself had plenty of readers in need of convincing; those presumably unmoved by the question 'where's the harm?' cited by the letterwriter above. The niupepa obviously had an audience that could read fluently in reo Māori, and perhaps reading in English was just one step too far for them. Alternatively, those the writer sought to convince of the value of reading may have been non-literate, listening in a group to the niupepa being read aloud. Regardless, it is clear from this letter that there were significant differences of opinion circulating around the value of reading, at least in the English language. Indeed, it is likely, and the many articles about reading may reinforce this point, that many Māori at the end of the nineteenth century did not read,. The writer, 'Te Mahara', laments that streams of Māori graduates were leaving the Māori

${ }^{211}$ Te Puke ki Hikurangi, Vol.2, No.29, 1899, p.6. [trans. FDB]

212 Ibid. 
schools Hukarere and Te Aute College and immediately turning their backs on book-learning, or, just as worrisomely, on reading the Māori niupepa. Māori secondary education at this point focussed heavily on basic literacy and numeracy, followed by vocational training, and this was conceivably not an environment in which most children's love of literacy flourished.

Like many others previously cited, 'Te Mahara' obviously felt that Pākehā knowledge was what had allowed Pākehā to ascend to a position of power, and that Māori too should actively seek after this knowledge. Perhaps unsurprisingly, this was a recurring theme in the Anglican niupepa of He Kupu Whakamarama and Te Pipiwharauroa, and may well have been more muted in general discourse. It does, however, also appear in Te Puke ki Hikurangi, the only other niupepa extant at the time which were largely in favour of their readers retaining and using their literacy. Without a more representative written record of the thoughts and reactions of Māori to this philosophy as it applied to reading, it is impossible to know if this positive reaction to Pākehā knowledge and reading in particular was representative. 'Te Mahara' makes it abundantly clear that from his perspective, reading was a social and spiritual good as well as an economic good. These three positive traits are not, however, separated from each other, but rather presented as part of a holistic model of wellbeing, centred on taking any new opportunities offered by new texts.

Māori reading was not, however, merely opportunistic. The selection of texts translated, and the engagement of those editors and translators who presented texts to their readers, shows that Māori engaged with care and deliberation in reading culture.

A further reason reading was engaged in was as a form of collective memory-making. While the majority of the reasons for reading cited above are to do with the integration of Pākehā content with the Māori language and Māori contexts, a great deal of Māori content was also made available to readers in reo Māori. Readers of the Anglican niupepa, in particular, were great collectors of pēpehā and waiata. The editors of these niupepa would actively seek out 
submissions of pēpeha from their readers, explaining ${ }^{213}$ that their aim was to preserve these pēpeha in print, lest they be lost with a generation that remembered them and was unable to pass them on orally to the next generation. Long lists of pēpeha, along with explanations of their provenance and meaning, appeared in Te Pipiwharauroa until February $1910 .{ }^{214} \mathrm{~A}$ semi-monthly series appeared for the first time in Te Pipiwharauroa in June $1908^{215}$ with a full list of pēpeha, without translation, explanation or context. Roughly alphabetised, they were printed as full-page features until January 1909, after which the volume published declined, disappearing entirely from February $1910^{216}$. A short explanation was included from 1909, explicitly stating the reason for the publication of the pēpeha: 'These have been collected for the sake of years to come, that they may be grasped correctly and in their entirety' ${ }^{217}$. The unmistakable inference is that the editors of the paper were concerned that, if the pēpeha were not preserved in print, they would be lost with the oral record.

A recurring argument was around the use of reading as a tool for preserving reo Māori. This was discussed in parallel with an ongoing conversation around the usefulness of schoolchildren learning to read and write in the English language. The author makes a plea for readers to continue to support niupepa, as 'our language will not grow if not supported by the iwi." 218 However, he acknowledges that the number of readily available texts in reo Māori is very small, and that excluding the Bible, the niupepa were the only other fairly reliable source of new reading material. The focus of the writer is much less, however, on the language medium of reading, and much more on the influx of new stories and ideas from other, Pākehā centres. Writers in Te Toa Takitini niupepa a little later in the century (1928, after the demise of all but one niupepa) lament that 'children's language has become Anglicised wherever you go. Māori are writing [and reading] the newspapers and Pākehā books. Every day,

\footnotetext{
${ }^{213}$ Te Pipiwharauroa, No.134, May 1909, p.11.

${ }^{214}$ Te Pipiwharauroa, No.142, June 1908, pp.1-12.

215 'He Whakatauki, he titotito, he pepeha', Te Pipiwharauroa, No.123, June 1908, p.7.

${ }^{216}$ Te Pipiwharauroa, No.142, June 1908, pp.1-12.

217 Te Pipiwharauroa, No.134, May 1909, p.11. (trans. FDB)

218 Te Mahara, 'Te Korero Pukapuka', in Te Pipiwharauroa, No. 45, November 1901, p.2.

p. 2. [transl. FDB]
} 
and every week, they are surrounded by the languages of the world." ${ }^{219}$ With the narrowing of options for reading in reo Māori, literacy for reo Māori readers had become a double-edged sword. Reading as a means to get ahead was still advocated, but, as this writer alludes to, opportunities for reading in their own language were few and far between, and reading became yet another exercise in engaging in a foreign medium.

Finally, readers read for a sense of fulfilment and self-recognition. One article submitted to Te Pipiwharauroa in 1901 begins with a quote from Francis Bacon, translated "Reading maketh a full man" ${ }^{220}$, and goes on to state a converse proposition; that a man who is ignorant of writing and reading books must be miserable. ${ }^{221}$ Such a miserable state is also extended to those who are in the company of literate friends, but must merely wait to be read the newspapers, the Bible and any letters they receive. Like many other references to literate Māori reading to companions, this is a casual aside. However, it is notable that here, collective reading is criticised because of a supposed disadvantage at which it places the illiterate listener. Why, the letter-writer asks, do not all ministers ensure that their parishioners are able to read and write? ${ }^{222}$

As discussed in a previous section, paratexts, particularly commentaries on texts by their translators or publishers, provide an insight into readers' reasons, a window into prescriptive and descriptive discussion of Māori reading. Te Toa Takitini in particular hosted nuanced discussions of reading. These, in turn, informed the presentation of translated texts and the ways in which the newspaper urged its readers to engage with the texts. Te Toa Takitini and its predecessor publications published many translated texts, with prescriptive suggestions for pertinent points the reader might gain from it. An exemplary specimen is the 1903 publication of 'Hiha Huriu', an excerpted digest of Brutus'

\footnotetext{
219 'Te Rau Tau Hou, 1928', in Te Toa Takitini, No.78, 1 February 1928, p.728.

${ }^{220}$ Te Mahara, 'Te Korero Pukapuka', in Te Pipiwharauroa, No. 45, November 1901, p.2. “Ma te korero pukauka ka ranea ait e tangata" [trans. FDB]

${ }^{221}$ Te Mahara, 'Te Korero Pukapuka', in Te Pipiwharauroa, No. 45, November 1901, p.2. “He tangata hoha, he mea e pouritia ana te tangata he kahore e mohio ki te tuhituhi ki te korero pukapuka" [trans. FDB]

222 Ibid. [trans. FDB]
} 
speeches and other aspects of the plot of Shakespeare's Julius Caesar. The excerpt, which consists of translated lines from the play interspersed with a summary of the play's context, is book-ended by the (unidentified) editor's comments, which take two different emphases. 'Hiha Huriu' is introduced in this fashion (emphasis mine):

These writings are a collection of the writings of William Shakespeare, of the speeches of Marc Antony, who, it is said, was one of the best speech-makers ever to speak to man. All Shakespeare's writings are significant to Pākehā, and children are taught these writings at school, if a Pākehā doesn't know these writings, he will not be known as an intelligent man. So, my friends, read closely, and think carefully on these writings.

The refrain that it was imperative for Māori to become more educated in Pākehā knowledge was, of course, a familiar one. However, where the earliest reo Māori newspapers had urged Māori to read widely and well, bluntly stating that acquiring literacy was an imperative, ${ }^{223}$ niupepa such as $\mathrm{He}$ Kupu Whakamarama, Te Pipiwharauroa, and Te Toa Takitini develop this idea. Here, as in other articles, the niupepa urges Māori to adopt Pākehā knowledge in order to become more educated, but does so without denigrating or devaluing Māori knowledge. The barely-veiled implication is that it is right and good for Māori to gain Pākehā knowledge, for the sake of being an educated person, but at the same time, it is very clear that the ideal presented here is to be an educated Māori person, rather than integrating oneself into Pākehā life.

Another hope for readers at the beginning of the $20^{\text {th }}$ century echoed the idea that readers would be able to identify with the text, and in identifying themselves, accept any changes to their behaviour encouraged by their reading. The commentary that follows 'Hiha Huriu', however, proposes another reason to read. Following the summary of the characters' final moments, the commentary continues:

223 'E hoa ma, e nga tangata Maori katoa', in Te Karere o Nui Tireni, Vol.4, No.1, 1 January 1845, p.2. 
There are many words of wisdom within this passage; go over it three or four times, so it sinks into your spirit: - If a man carelessly insults others, he will look with contempt on the friends of his youth. Some half-caste children are teases, and act with contempt toward their Māori mothers, to their cousins, to their iwi, their language, and they don't know whence they are from.

In part, this was a way of relating the text's morals to the reader; that is, if the reader saw the text as relevant, its message or instructions could also be relevant to his life. Hiha Huriu's message to its readers, to take one example, further expands its example of half-caste children from a relational exercise to cautionary moral fable, warning about the treacherous nature of man.

The sins of a man will live on after he is gone. After our deaths, our sins will live on after us, and in our children, or in those who've fallen to the harm of our actions. Our acts of goodness will also live on after us.

To summarise the teachings in Shakespeare's words: -

1. The glory of this world is but fleeting

2. The danger of a jealous nature is the goodness of its pleasant speech

3. Most people can be turned from their path by skilful pleasant words

4. The evil of one man towards another springs from thought only for their own gain. Since some people do not approve of ministers attempting to work for their common good, they live still.

5. The firm friendship of the closest of friends is that between Antony and Caesar.

6. The downfall of a man will be his sins, no matter how long he may live.

Here, the niupepa contends that a story written in English, based on well-known stories and European history, still had something of relevance to Māori readers of the early $20^{\text {th }}$ Century and their behaviour. In this particular extract, the editor and translator, Kohere, argues for the moral good of acting fraternally within families and community, implying that while race relations in predominantly Māori communities, or among mixed-parentage children, was a fraught area, lessons could be drawn from the Shakespearean presentation of Roman history. The moral argument, alongside its plea for brotherly behaviour and 'firm 
friendship', implicitly relies on the importance of introduced literature as a means to communicate the editor's own concerns about his society. In keeping with the niupepa's history, Kohere's advice crossed cultural boundaries, and applied concepts familiar to Māori culture to new material. To the reader, Julius Caesar is presented as a legendary figure, like Māui and Kupe.

Moreover, the editor who wrote this commentary clearly intended it to be useful as a moral text to his readers. This theme is echoed in a 1903 composite piece in Te Pipiwharauroa on the dangers of sloth, which borrows texts from a variety of Spanish and English proverbs to reinforce its message; that "taihoa" is one of the very worst enemies of the Māori people"224 and "both Māori and Pākehā have proverbs about the concept of "taihoa"'. 225 Pākehā writings, here, are very clearly presented as a source of useful information, and equally creditable as more familiar Māori proverbs. Kōhere, writing for Te Toa Takitini and Te Pipiwharauroa, was adept in inserting excerpts from his knowledge of English literature in order to illustrate a point about public health or daily life. Thomas Grey's Elegy Written in a Country Churchyard added relish and poignancy to a long piece written on the importance of maintaining 'enjoyment of the body, enjoyment of the mind, and enjoyment of the spirit', in which Kohere argues that manual work is not to be despised. Similarly, Robert Burns is co-opted in an article about public health and fleas, with a few lines from his poem "To a Louse" translated by Kohere and inserted with the comment that, just as the louse in the poem does not shy from biting a fine lady, a flea does not distinguish between who it bites either ${ }^{226}$ - and thus the attendant health risks. Both articles, in fact, take the use of these passages further. Through using them to illustrate his public information articles, Kohere asks readers not only to accept the texts as worthy of knowledge and

\footnotetext{
224 'Taihoa', in Te Pipiwharauroa, No.65, July 1903, p.2.

225 ibid.

226 'Ratou', Te Toa Takitini, No.3, September 1931, p.31.
} 
credible, but also to incorporate them into a larger narrative around how to live their own lives. Kohere evidently moved fluently between the domains of reading literature and lived experience, and the domains of traditional Māori literature and imported, translated literature. Whether or not the majority of his readers were equally comfortable with such texts is unclear, but they were, with excerpts such as these, given every opportunity to engage in reading as a learning tool.

The idea that literature and ancestral stories could contain useful morals or allegories for the reader was, of course, not a new one. Māori communities had long been well-supplied with iwi pēpeha and whakatauki intended to make a point, in addition to well-known stories illustrating character traits.

A further implication of readers identifying themselves in the text, however, was that through reading texts translated from other cultural contexts, the reader would come to a deeper understanding of his own culture and surroundings. This may have been evident both in texts that are applied by their translators to the reader's own life, and in those texts which directly compared Māori lives and custom to other cultures. This brings an entirely new element into the reasoning around reading imported literature: the concept that the literature was valuable as a measure of identification with other cultures, and a gesture toward fostering a shared cultural store in reflection of this. Texts translated from Hawaiian underscore this, as do the pakiwaitara texts published in Te Pipiwharauroa from Grey's book of Polynesian mythology - a strange blend of traditional Māori stories and Pākehā interpretation, reflected back to the reader. Even the struggles of minorities from within Pākehā groups, such as the nationalist poetry of Robert Burns, were translated and held up as a comparable example for Māori readers.

A series of Hawaiian songs and legends, translated into Māori and published with an accompanying interview and detailed 
commentary, appeared in Te Pipiwharauroa in 1907 and 1908, and were briefly discussed above. An important additional feature of this series, however, was its positioning of readers. Early in the series, the article published in the November 1907 edition of the niupepa, having previously introduced a visiting Hawaiian soldier, John Tamatoa Baker ${ }^{227}$, declares that "we consider it a good thing to compare our own stories of the past to the stories of our cousins, who live on the numerous islands of the sea, to determine if their stories of ancient times are also cousins of our own stories." 228 The writer then goes on to explain a contemporaneous theory of Māori migration through the Pacific and Indian subcontinent, and bring the discussion to the Māori legend of the Hawaii homeland and the legendary figure of Tamahuarere. A song in Hawaiian about this figure, possibly recognisable in Māori mythology, is presented and translated into reo Māori. This is further followed by a translation of a song by 'Makuakuamana... a man standing to be king for Hawaii. This is very similar to the story of Maui raising Aotearoa. Maui is a name well-known among the indigenous ${ }^{229}$ of Hawaii'. ${ }^{230}$

With these two pieces, and the three follow-up articles in subsequent issues of the niupepa, the writer makes it very clear that he intends to make a point about the origins of Māori, and therefore a point about the origins of his readers. Readers are introduced to the contention that the 'Māori o Hawaii' are cousins, and this idea is demonstrated through the medium of translated literature in particular. Kohere makes what is, in despite of presenting other evidence, quite a convincing case that the stories and language presented here together have a common origin. Moreover, the reader is invited to be intrigued, informed and

\footnotetext{
${ }^{227}$ Baker, John Tamatoa, Kohere, Reweti (as 'Tipiwhenua')(trans.), 'He Waiata No Hawaii', in Te Pipiwharauroa, No.116, November 1907, p.4.

228 Ibid.

${ }^{229}$ The word I have here translated as 'indigenous' is 'maori' in the original text. Te Pipiwharauroa and other contemporaneous sources regularly used 'maori' in the sense of 'indigenous' or 'natural'.

${ }^{230}$ Ibid.
} 
entertained by the texts. Readers are encouraged to incorporate the waiata and the theories around them into their own conceptions of themselves, their place in the world, and relative position of others. That position, as presented here, is one of common fellowship, and is mediated through a shared literature, and through reading.

Governor George Grey was an assiduous collector of Māori stories from various informants, and responsible for the publication of his own collection, Polynesian Mythology. ${ }^{231}$ Niupepa were, likewise, assiduous in collecting and presenting their own stories. These two strands of collecting and reflecting Māori stories came together in Te Pipiwharauroa in 1909, when the niupepa published excerpts from Grey's book as a source of pakiwaitara. Governor Grey's works, as pioneering works in reo Māori of how Māori were presented to themselves, must have found a wide readership. It may have been that niupepa even kept short pieces by Grey in reserve to publish when the pickings of other pieces were slim. Although it seems a strange path for a Māori story to take to be collected by a Pākehā official before being presented back to a reo Māori-reading audience, it may have, in fact, been an easier task for printers to publish from an extant anthology than to ask local kaumatua to send in their own versions of the stories. Moreover, these stories may have had input from Te Rangikāheke, ${ }^{232}$ a Ngāti Rangiwēwehi chief and scholar who provided Grey with many of the stories which formed the basis of his collection Ko nga mahinga a nga tupuna Māori (Later Polynesian Mythology). As such, the links back to iwi knowledge from the stories as here presented were, indeed fairly close. Grey also comments in the preface to the first edition of (the English-language) Polynesian Mythology that to gather together the stories contained therein, he had 'collected a large mass of materials,

\footnotetext{
${ }^{231}$ Sir George Grey, Polynesian Mythology and Ancient Traditional History of the New Zealand Race (Auckland: H Brett, 1885).

${ }^{232}$ Ranginui Walker. 'Māori studies - ngā tari Māori - Pioneers of Māori studies', Te Ara - the Encyclopedia of New Zealand, updated 19-Nov-14, URL: http://www.TeAra.govt.nz/en/maoristudies-nga-tari-maori/page-1.
} 
which were, however, from the manner in which they were acquired, in a very scattered state; for different portions of the same poem or legend were often collected from different natives, in very distant parts of the country $^{\prime 233}$ - evidently, a range of chiefs throughout the country had been consulted for these stories to make it to the page, and many shared their stories with other groups. Although the presentation of Grey's stories in the niupepa raised no discernible comment in subsequent editions, making it difficult to know how readers responded to this particular publication, it is clear that Grey was a very popular source of reading material for reo maori readers of the time. While translated stories from other cultures were also presented as relevant and universally applicable to Māori, stories immediately reflecting back familiar characters and themes such as these were also a popular part of reading. These stories told communities about themselves, and presented in this form, a reader was both presented with both a depiction of their own or a familiar community, and the lens of another culture. This piece of cultural borrowing may have had considerable novelty value. Readers, it seemed, were happy to read in order to see themselves in print, and learn or re-encounter their own stories.

Recognising both oneself and universally applicable wisdom in literature was another argument made for reading at the time. The writing of Reweti Tuhorouta Kohere, a scholar and translator who for many years edited and wrote for Te Pipiwharauroa, provides a well-documented example of a reader who not only found fulfilment in reading, but sought to divine the meaning in the Pākehā texts he read and relate it to his own life and experiences. Kohere was associated with Te Aute College $\mathrm{e}^{234}$ and from his youth was a passionate reader interested in Pākehā texts, and a prolific translator. Through contributions to niupepa, he sought to inspire other readers to appreciate the new texts opened to them in reo Māori translation.

\footnotetext{
${ }^{233}$ Sir George Grey, Polynesian Mythology and Ancient Traditional History of the New Zealand Race (Auckland: H Brett, 1885), p.viii.

${ }^{234}$ Reweti Kohere, The Autobiography of a Maori (Wellington: Reed, 1951), p.27.
} 
Kohere's own translations appeared many times in the Anglican niupepa, often accompanied by sensitive commentaries in which he would lay out his interpretation of the piece, its impact on himself personally, and its application for Māori readers. For Kohere, literature from another culture was a powerful source for self-improvement and provided texts with which he identified, and recognised as reflecting something relevant in himself back to the reader. Although his roots as a reader were in his early education and fascination with literature, Kohere's writings and translations were more often published via the niupepa in the early twentieth century.

Kohere encouraged other readers to carefully read and enjoy foreign texts, as he did. In a translation of Hamlet, published in Te Pipiwharauroa in 1912, Kohere admits that, although he was the text's translator, he does not fully understand the text ${ }^{235}$. He suggests, however, that the reader should "think the text over; revolve it in the mind secondly, and thirdly talk about it, and translate the stubborn words into Māori." ${ }^{236}$ Like Te Mahara, Kohere was attracted to Māori self-determination through judicious use of whatever tools were available, and was also an advocate for reading as a means of personal fulfilment.

Steeped in knowledge of global texts and a fluent reader in English, Kohere found an unexpected expression of his own experiences and thoughts in the poetry of Robbie Burns. Kohere, a voracious and widely-read reader, often included extracts from Burns' poetry, in the original English with reo Māori gloss, in the niupepa, particularly in Te Toa Takitini. These extracts were usually short snippets, bookended by Kohere's musing on their significance to his own life, and, as an extension of this, the truisms contained in such lines as 'a man's a man for a' that, and $a^{\prime}$ that ${ }^{\prime 237}$ applicable to others of his readers. Introducing the couplet 'oh wad some power the giftie gie us / to see oorsels as ithers se

\footnotetext{
235 'He Korero no te Matauranga: Hamlet', in Te Pipiwharauroa, No.172, September 1912, p.11.

236 'He Korero no te Matauranga: Hamlet', in Te Pipiwharauroa, No.172, September 1912, p.11.

237 'He Kupu Tohunga', Te Toa Takitini, No.39, 1 January 1924, p.118.
} 
eus $^{\prime 238}$, Kohere exclaims that 'I have a fondness for Brown; he's an accomplished expert at expressing such things'. The themes of helplessness, regret and care for other creatures in Burns' poem 'To A Mouse' are also elaborated on at length, ending with the sombre reflection 'What can one do? Such tragedies occur both to mice and men $^{\prime 239}$. That literature could be valuable in itself as a source of enjoyment and self-reflection, as well as the more common source of social commentary, was a muted but important thread at the beginning of the twentieth century.

While reading in English came in for criticism in New Zealand at the beginning of the $20^{\text {th }}$ century, it was largely for the content of what the readers engaged with, and whether it were appropriate for an educated man to read fiction, as discussed previously. For Māori, debate around reading and reasons for reading took nothing for granted. From those who saw reading as a luxury, available only to the well-off and the well-educated, to those who were concerned that reading would become just another means of assimilation, forcing Māori into engaging in English and forgetting their own language and literature, reading certainly had its detractors. There were, however, others who saw reading as an opportunity. Pragmatics such as the pseudonymous 'Te Mahara' discussed reading as a means by which Māori could access knowledge developed by Pākehā for their own benefit and betterment. Collectors of pakiwaitara, pēpeha and waiata in the niupepa could read collections of these forms of Māori literature in the Anglican niupepa, a deliberate stop-gap measure against language loss. Others, such as Ngata and Kohere, read eagerly for the sake of enjoyment and personal growth through the translated texts of others, and a belief in the applicability of texts as foreign as Shakespeare's Julius Caesar to the context of nineteenth century Māori. These writers also encouraged other readers to take up the challenge of reading and integrating a knowledge of translated literature into their lives. In the eyes of Kohere, Ngata and other

\footnotetext{
${ }^{238} \mathrm{Ibid}$. Translated 'Aue, me i whai Mana ki te homai kanohi ki a tatou / Kia kite ai tatou I a tatou me te kite a era atu'.

${ }^{239}$ Ibid.
} 
writers in the Anglican niupepa, growth through reading could be a means by which Māori developed their thinking as well as their social position, becoming more in control of their self-determination. Overall, the reasons Māori read were as multitudinous as the number of times books were taken up, and as contextspecific. However, it is evident that many saw reading as a means by which their actions could be shaped, their knowledge widened, for whether for good or ill; or simply for an enjoyable experience. 


\section{Bibliography}

\section{Primary Sources:}

\section{Niupepa:}

Te Karere o Nui Tireni, Auckland, January, 1842-1846. Vol.1, no.1 - Vol.5, no.1.

The Anglo-Maori Warder, Auckland, 1848. Vol. 1 no. $1-26$.

Te Karere Maori, Auckland, 1849-1854. Vol. 1 no. 1 - vol. 6, no. 140.

Te Karere o Poneke, Wellington, 1857-1858. Vol. 1 no. 1 - 58.

Aotearoa, Auckland, 1861-1862. Vol. 1. No. 1-2.

Te Waka Maori o Niu Tirani, Gisborne, 1871-1877 vol. 8 no. 1 - Vol. 13b, no. 13., 1878-1879, Vol. 1, no. 1 - 42.

Matariki, Auckland, 1881. No 1 -2.

Te Korimako, Auckland, 1882-1888. Vol. 0. No. 1 - Vol 1. No. 8.

Te Hoa Maori, Auckland, 1885-1895.

Te Paki o Matariki, Maungakawa, Waikato, 1892-1895.

Huia Tangata Kotahi, Hehitingi, 1893-1895.

Panui Whakawa Whenua Maori, Maungakawa, Waikato, 1894-1896.

Te Puke Ki Hikurangi, Greytown North, 1897-1913. Vol. 1, no. 1 - Vol. 7, no. 40.

Te Tiupiri, Whanganui, 1898-1900.

He Kupu Whakamarama, Gisborne, 1898-1902.

Te Pipiwharauroa, Te Rau Press, Gisborne, 1899-1913. No. 59-180.

The Maori Record, Normanby, 1905-1907.

Te Kopara, Gisborne, 1913-1921.

Te Toa Takitini, Hastings, 1921-1932. Vol. 1, no. 1 - Vol. 1 no. 7.

\section{Individual Articles:}

'E hoa ma, e nga tangata Maori katoa', in Te Karere o Nui Tireni, Vol.4, No.1, 1 January 1845, p.2.

'He Kupu Tohunga', Te Toa Takitini, No.39, 1 January 1924, p.118.

'He Wharangi Tuwhera', Te Waka Maori o Niu Tirani, Vol.12b, No.2, 25 January 1876, pp.14-15.

'Ko Paratene Ngata Kua Moe I te Moengaroa', Te Toa Takitini, No.42, 1 January 1925, pp.161-162. 
'Kaore E Tau te Hee', in Te Puke ki Hikurangi, Vol.2, No.6, 15 May 1899, p.6. 'Ko te Karere Maori', in Te Karere Maori, Vol.1, No.12, 7 June 1849, p.1.

'Kotahi Tetahi Mahi Nui', in Te Puke ki Hikurangi, Vol.2, No.21, 30 December 1899, p.6.

'Mangonui', in Te Waka Maori o Niu Tirani, Vol.12b, No.12, 13 June 1876, pp.139-145.

'Nga Mema o 'Te Tiupiri', in Te Tiupiri, Vol.1, No.2, 11 January 1898, pp.1-3.

'Mo Nga Poropiti Tenei Korero', in Te Puke ki Hikurangi, No.21, 7 February 1899, p.1.

'Panui Whakamarama', in Te Puke Ki Hikurangi, Vol.6, No.13, 12 June 1905, pp.78.

'Ratou', Te Toa Takitini, No.3, September 1931, p.31.

'Speeches of Maori Members', Te Waka Maori o Niu Tirani, Vol.12, No.21, 2 November 1875.

'Te Korimako Hou', in Te Korimako, Vol. 1, No. 5, 6 June 1890, p.1.

'Te Pukapuka', in Te Pipiwharauroa, No.133, April 1909, pp.12.

'Te Rau Tau Hou, 1928', in Te Toa Takitini, No.78, 1 February 1928, p.728.

'The members of 'The Jubilee', in Te Tiupiri, Vol.1, No.1, 4 January 1898, pp.4-6.

'The Old Frontier: He Pukapuka Hou', in Te Toa Takitini, No.31, 1 February 1924, p.13.

'Untitled', Te Karere o Nui Tireni, 1 January 1842, p.1.

'Untitled', Te Karere Maori, Vol.1, No.2, 19 January 1849.

'Untitled', in Te Karere Maori, Vol.1, No.37, 26 July 1858, pp.3-4.

'Untitled', Te Pipiwharauroa, No.134, May 1909, p.11.

'Whare Pukapuka, Ara, (Library.)', in Te Puke ki Hikurangi, Vol.2, No.2, 15 January 1900, p.7.

Chamberlain, J, in Te Tiupiri, Vol.1, No.15, April 12 1898, p.7.

H.P.M., in Te Tiupiri, Vol.1, No.7, 15 February 1898, p.4.

Kaawhe, W. E., 'Kite Etita', in Te Tiupiri, Vol.1, No.2, 11 January 1898, pp.3-4.

Kohere, Reweti, 'He Whakamaramatanga', in Te Pipiwharauroa, No. 63, May 1903, p.5.

Nguha, Te Waka Maori o Ahuriri, Vol.1, No.4, 25 July 1863, p.3.

Peka, Hohepa, in He Kupu Whakamarama, No.9, 1 November 1898, pp.4-5. 
R.W.W., 'Ko Kiriki: Whakaakoranga i te hunga tamariki', in Te Karere o Poneke, Vol.1, No.25, 26 April 1858, p.3-4.

Tangata, Renata, et al, 'Te Matenga o Ripeka', in Te Waka Maori o Niu Tireni, Vol.11, No.5, 9 March 1875, p.56.

Te Mahara, 'Te Korero Pukapuka', in Te Pipiwharauroa, No. 45, November 1901, pp.2-3.

Terawharitua, Wi Hapi, Te Karere o Poneke, Vol.1, No.15, 31 December 1857, p.2-3.

Titipere, Hori, 'He Pukapuka Reo Maori', Te Korimako, Vol.0, No.73, 16 March 1888, p.11.

Stafford, E. W., Te Karere o Poneke, Vol.1, No.25, 26 April 1858, p.2-3.

\section{Translated texts in Niupepa:}

'Anorokiri me te Raiona', in Te Karere Maori, No.12, Vol.1, 7 June 1849, p.1-2. Translation of 'Androcles and the Lion'.

'E, te Whakama i a au', in Te Pipiwharauroa, No.103, October 1906, p.9.

'Eh[sic] Kupu ki nga Whaea: Te Kainga me te Tane', in te Pipiwharauroa, No.89, August 1905, pp.3-5. Translation of original by Mrs. C Northcote.

'He Himene', in Te Pipiwharauroa, No.102, September 1906, p.2.

'He Himene Marena', in Te Pipiwharauroa, No.138, September 1909, p.11.

'He Korero no te Matauranga: Hamlet', in Te Pipiwharauroa, No.172, September 1912, p.11. Translation of Hamlet, William Shakespeare (London, ca.1599). Trans. Reweti Kohere.

'He Kupu ki nga Whaea: Te whaea raua ko Tana Tamariki', in Te Pipiwharauroa, No.88, July 1905, pp.2-3. Translation of original by Mrs. C Northcote.

'He Kupu ki nga whaea: Te Whakahaere', in Te Pipiwharauroa, No.91, October 1905, p.4-6. Translation of original by Mrs. C Northcote.

'He Manuhiri no Hawaii', in Te Pipiwharauroa, No.114, September 1907, pp.4-5.

'He Moemoea', in He Kupu Whakamarama, No.4, June 1898, p.1.

'He tamariki!', in Te Pipiwharauroa, No.66, August 1903, p.10. Translation of speech by William Pitt the Younger.

'Hiha Huriu', in Te Pipiwharauroa, No.69, November 1903, p.6. Translation of Julius Caesar, William Shakespeare (London, 1599). Trans. Reweti Kohere.

'Himene Marena', in Te Pipiwharauroa, No.86, May 1905, p.11.

'Himene', in Te Pipiwharauroa, No.139, October 1909, p.10. Translation of 'There's Not a Friend', Johnson Oatman (1895). 
'Himene mo te Whakapuwaretanga o te hahi o te Tokotoru Tapu i Manutuke, Maehe 1913', in Te Pipiwharauroa, No.176, March 1913, p.9.

'Ko te Pukapuka o Pomare, te Kuini o Tahiti, Ki A Rui Piripi, Te Kingi O Wiwi' (reo Māori trans.), in Te Karere o Nui Tireni, Vol.4, No.3, 1 March 1845, p.10. Translation of a letter by Queen Pomare IV.

'Ko te raiona me te kiore', in Te Karere Māori, Vol.1, No.15, 19 July 1849, p.4. Translation of 'The Lion and the Mouse'.

'Ko te toenga iho o te pukapuka o Pomare te Kuini o Tahiti ki te kingi o Mariao' (reo Māori trans.), in Te Karere o Nui Tireni, Vol.4, No.5, 1 May 1845, p.18. Translation of a letter by Queen Pomare IV.

'Na Hakepeare', in Te Korimako, Vol.0, No.26, 15 April 1884, p.8, and in Te Tiupiri, Vol.2, No.54, 11 May 1899, p.6. Translation of var. works of William Shakespeare.

'Nga Kahika', in Te Karere Maori, Vol.1, No.24, 22 November 1849, p.4. Translation of 'The Sofa', William Cowper (England, 1785). 'Nga Karaipiture: Hoani Karihotoma', in Te Pipiwharauroa, No.136, July 1909, p.9.

'Taihoa', in Te Pipiwharauroa, No.65, July 1903, p.2.

'Te Ingarihi I Itari', in Te Karere Maori, Vol.1, No.7, September 1855, p.22. Translation of 'the English in Italy'.

'Te Kainga Tupu', (trans. Apirana Ngata), in Te Pipiwharauroa, No.141, December 1909, p.10. Translation of 'Home Sweet Home', John Howard Payne (1823).

'Te Kuri i te Whare Tarutaru', in Te Karere Maori, Vol.1, No.24, 22 November 1849, p.4. Translation of 'The Dog in the Manger'.

'Te Mahi A Te Ra Hapati', in Te Pipiwharauroa, No.137, August 1909, pp.6-7.

'Te Mangere', in Te Pipiwharauroa, No.66, August 1903, p.8. 'Te Tangata me te Maramara Rakau', in Te Karere Maori, Vol.1, No.26, 20 December 1849, p.4. Translation of 'The South Sea islander and the Talking Chip', in Williams' Missionary Enterprise, (London, n.d.).

'Te Matenga o te Tau', in Te Karere Maori, Vol.1, No.26, 20 December 1849, p.4. Translation of 'Complaint of the Dying Year', Dr Henderson (Edinburgh: Edinburgh Star, n.d.).

'Te Ngaro Hanga Honi', Te Karere Maori, Vol.1, No.25, 6 December 1849, p.4.

'Te Raeona', in Te Karere Maori', Vol.1, No.25, 6 d=December, p.4. Translation of Travels in the Interior of Southern Africa, William John Burchell (London, 1824).

'Te Tupapaku', in Te Karere Maori, Vol.1, No.25, 6 December 1849, p.4. Translation of 'The Murdered Traveller', William Cullen Bryant, in Samuel Kettel (ed), Specimens of American Poetry (Boston: S. G. Goodrich and Co., 1829). 
'Te Wharua Whakamate', in Te Karere Maori, Vol.1, No.25, 6 December 1849, p.4. Translation of 'Poison Valleys in Java and Italy, in The Gentleman's Magazine and Historical Chronicle (London, 1831).

'The Sword and the Pen' 'He Korero-tito: Te hoari me te penetuhituhi', in Te Karere Maori, Vol.1 No.18, 30 August 1849, p.4. Translation of 'The Sword and the Pen'.

Baker, John Tamatoa, Kohere, Reweti (as 'Tipiwhenua')(trans.), 'He Waiata No Hawaii', in Te Pipiwharauroa, No.116, November 1907, p.4.

Kemp, Henry Tacy, Ko te haerenga o te manene: $i$ haere atu ai ia i tenei ao ki tera ao atu (Wellington, 1854), in Te Pipiwharauroa, No.71, January 1904, p.8. Translation of Bunyan, John, The Pilgrim's Progress (London, 1678).

Baker, John Tamatoa and Reweti Kohere (as 'Tipiwhenua') 'He Waiata No Hawaii: Waiata mo Kahai (Tawhaki)', in Te Pipiwharauroa, No.120, March 1908, p.7.

Baker, John Tamatoa and Reweti Kohere (as 'Tipiwhenua')(trans.), 'He Waiata No Hawaii: He Inoi ki a Rongo', in Te Pipiwharauroa, No.120, April 1908, p.9.

Baker, John Tamatoa and Reweti Kohere (as 'Tipiwhenua')(trans.), 'He Waiata No Hawaii: He Waiata mo Tu', in Te Pipiwharauroa, No.124, July 1908, p.11.

Grey, George, 'Ko te Patunga o Tau-a-Porirua: He taniwha no Heretaunga', in Te Pipiwharauroa, No.132, March 1909, p.11.

Grey, George, 'Te Aohuruhuru', in Te Pipiwharauroa, No.133, April 1909, p.11.

Grey, George, 'Hine-poupou Raua Ko Te Oriparoa', in Te Pipiwharauroa, No.135, June 1909, p.3.

Grey, George, 'Whakatauihu', in Te Pipiwharauroa, No.175, January 1913, p.1.

Kohere, Reweti (trans.), 'E Ihu, E Te Hoa', in Te Pipiwharauroa, No.104, November 1906, p.7.

P. W. M, 'Te Tangata Tino Mangere o te Ao', in Te Pipiwharauroa, No.110, May 1907, p.5.

\section{Newspaper Articles}

'Miscellaneous', The Spectator, 14 September 1844, p.10. http://archive.spectator.co.uk/article/14th-september-1844/10/ miscellaneous.

'The Maoris and Royalty', in The Press, Vol.58, No.10991, 14 June 1901, p.4.

'The Carnegie Offer: Proposed Free Library', in Timaru Herald, Vol.89, No.13063, 25 August 1906, p.2.

'The Maori's Comment: 'Py Korry - The Lyddite", in The Auckland Star, Vol.70, No.177, 29 July 1939, p.14. 


\section{Translated texts}

Agathos: ko te ritenga o te ingoa nei, ko te tangata pai / kua oti te tuhituhi i reo Māori pakeha e Samuel Wilberforce (Waimate: Bishop's Press, 1843). Translation of 'Agathos' in Samuel Wilberforce, Agathos and Other Sunday Stories (London: R. B. Seeley and W. Burnside, 1840). Trans. James Davis and Thomas Williams. BIM 190.

He Kohikohinga No Roto I nga Karaipiture Tapu no te hanganga o te ao tae noa ki te whanautanga o to tatou Ariki, Lady Ann Martin (London: Society for Promoting Christian Knowledge, 1882). Translation of Outline of Scripture History (London, 1876). Trans. Williams, L. W. BIM 1035.

He Korero Tenei Mo Ani Kanara, (Waitangi: Colenso's Press, 1847). Trans. William Colenso BIM 334.

He Korero Tipuna Pakeha no mua, ko Ropitini Kuruho, Tona Ingoa, (Wellington: 'Independent' press, 1852). Translation of Robinson Crusoe, Daniel Defoe (London: w. Taylor, 1719). Trans. Henry Tacy Kemp. BIM 427.

He pukapuka ako tenei i nga ritenga pai e-maha o roto o te taonga nei o te moni, i nga tikanga pai hoki, o te hokohoko, o te aha, o te aha (Wellington: Independent Office, 1852). Trans. Henry Tacy Kemp.

He Teneti e tū ana i te mania (Waitangi: Bishop's Press, 1845). Translation of 'The Tent on the Plain', in Samuel Wilberforce, Agathos and Other Sunday Stories, (London: R. B. Seeley and W. Burnside, 1840). BIM 259.

He Whakapapa Ara (Auckland: Williamson for the Church Mission, 1847). Translation of Friedrich Strass, A Summary of Scripture History to Solomon, based on Der Strom der Zeiten. BIM 365.

Ko e tahi hua o te whakapono, (Waimate: Bishop's Press, 1852). Translation of Pearl of Days , Barbara Farquhar (London, 1848). Trans. Martin, Ann. BIM 428.

Ko te haerenga o te manene: $i$ haere atu ai ia i tenei ao ki tera ao atu (Wellington, 1854). Translation of The Pilgrim's Progress, John Bunyan (London, 1678). Trans. Henry Tacy Kemp. BIM 451.

Nga Reme e Rua (London: Religious Tract Society, 1885). Translation of Mrs. Cameron, The Two Lambs (London, Houlston \& Wright, 1860), trans. Miss Harding. BIM 1125.

Nga tamariki Haereere Noa (Waimate: Bishop's Press, 1843). Translation of 'The Little Wanderers', Samuel Wilberforce, The Rocky Island and Other Parables (London: James Burns, 1840). Trans. Elizabeth Colenso. BIM 191.

Te Korero Tawhito, Tawhito (Palmerston North: J. P. Leary, 1888). Translation of The Story Wanted, Arabella Katherine Hankey (England: no printer, 1866). Trans. Ropihana Takana, BIM 1201. 
Te Korero whakatepe o te hahi karaitiana o te timatanga mai tae noa ki te tau 1517 (London, 1882?). Trans. Rev T. S. Grace. BIM 1030.

Te Motu Kowhatu (Waimate: Bishop's Press, 1844). Translation of 'Rocky Island', in Samuel Wilberforce, The Rocky Island and Other Parables (London: James Burns, 1840). Trans. Elizabeth Colenso. BIM 216.

Hemans, Felicia, 'The Hour of Prayer' in The Works of Mrs Hemans (Vol 4) (London: Blackwood and Sons, 1854), trans. T. H. Smith, in He Waiata, (Pūrewa: St John's College, 1851). BIM 409.

\section{Other sources}

30 April 1836, Missionary Register, No. 348, July 1839.

Auckland Star, 16 August 1872.

Brodie, Walter, Remarks on the Past and present State of New Zealand: Its Government, Capabilities, and Prospects (London, London Whittaker and Co, 1845).

Cowan, James, Legends of the Maori, Laments for the dead, p. 317, available from NZETC, URL http://nzetc.victoria.ac.nz/tm/scholarly/tei-Pom01Lege-t1body3-d5.html; accessed September 2014.

Grey, Sir George, Polynesian Mythology and Ancient Traditional History of the New Zealand Race (Auckland: $\mathrm{H}$ Brett, 1885).

Halse, Henry, ' 9 pages written 16 Feb 1856 by Henry Halse to Sir Donald McLean', 1856, ATL, Object \#1009779 from Ms-Papers-0032-0314. McLean Papers, http://mp.natlib.govt.nz/detail/?id=1009779\&l=mi; accessed 28 March 2014.

Henry Tacy Kemp, Revised Narrative of Incidents \& Events in the Early Colonizing History of New Zealand, from 1840 to 1880 (Auckland: Wilson and Horton, 1901).

Hocken, T. M. 'Some Account of the beginnings of Literature in New Zealand: Part I, the Maori Section', TNZI, Vol.33, 1900.

Lyon, William, Wellington Independent, 5 July 1873.

Native Schools Act 1858, s.9-10.

Native Schools Act 1867, s.15,18,21.

Ngata, Paratene, Te Pipiwharauroa, in Te Ohorere and Wiremu Kaa (eds), Ngā Kōrero o Reweti Kōhere mā (Wellington, Victoria University Press, 1994). 
Otaki Maori Land Court Minutebook - 26 March 1874, accessible at URL: http://horowhenua.kete.net.nz/en/site/documents/1833-otaki-maori-land-court$\underline{\text { minutebook-26-march-1874 }}$

Parkerson, two views of Tuhoromatakaka, in Weekly Graphic and New Zealand Mail, May 1910, in Pitt Rivers Museum, University of Oxford(Photographic Collection), 1998.277.19A, 1998.277.20A, 1998.2277.22.

Pomare IV Queen of Tahiti \& Pritchard, George, 1796-1883, Letters and prints (1843). Trove, http://trove.nla.gov.au/work/10953643; accessed 19 March 2015.

'Results of a Census of the Colony of New Zealand for the night of the 3rd March 1878 in The New Zealand Official Yearbook, 1878; URL http://www3.stats.govt.nz/historic publications/1878-census/1878-resultscensus.html\#idsect1 15058.

"Review”, New Zealand Journal, 6 July, 1844.

Southland Times, 22 July 1874.

Stout, Sir Robert, How and what to Read (Auckland: Book Exchange, 1908).

Swainson, William, New Zealand and its Colonisation (London, 1859).

Taylor, Henry, in Appendices to the Journals of the House of Representatives, 1862, A-51.

The New Zealand Spectator and Cook's Straight Guardian, 2 June 1852.

Wellington Independent, 21 July 1849.

White, John, unknown source, quoted in Johannes Andersen, 'Māori Printers and Translators', in Richard Alexander McKay (ed.) The history of printing in New Zealand, (Wellington: Club of Printing House Craftsmen, 1940).

Wilberforce, Samuel, Agathos and Other Sunday Stories (London: R. B. Seeley and W. Burnside, 1840).

Wilberforce, Samuel, The Rocky Island and Other Parables (London: James Burns, 1840). 


\section{Secondary Sources:}

Abbott, H. Porter, The Cambridge Introduction to Narrative (Cambridge: Cambridge: 2008).

Anderson, Benedict, Imagined Communities (New York: Verso, 1983).

Ballantyne, Tony, 'Christianity, Colonialism and Cross-cultural Communication', in John Stedhouse and G. A. Wood (eds.), Christianity, Modernity and Culture: New Perspectives on New Zealand History, Adelaide, 2005, pp. 23-58.

Ballantyne, Tony, 'Reading the Newspaper in Colonial Otago', Journal of New Zealand Studies, No.12, 2001, pp.47-64.

Calman, Ross, 'Māori education - mātauranga - Missionaries and the early colonial period', Te Ara - the Encyclopedia of New Zealand, updated 13-Jul-12, URL: http://www.TeAra.govt.nz/en/maori-education-matauranga/page-2.

Calman, Ross, 'Māori education - mātauranga - The native schools system, 1867 to 1969', Te Ara - the Encyclopedia of New Zealand, updated 13-Jul-12, URL: http://www.teara.govt.nz/en/maori-education-matauranga/page-3.

'Commentary on Te Karere Maori, 1849-1854', Niupepa Māori, URL http://www.nzdl.org/gsdlmod?gg=text\&e=d-00000-00---off-0niupepa--00-0----010-0---0---0direct-10---4-------0-1|--11-en-50---20-about---00-0-1-00-0--4----0-011-10-0utfZz-8-00\&a=d\&c=niupepa \&cl=CL1.3\&d=02 commentary, accessed 28 January 2015.

'Commentary on Te Puke ki Hikurangi', Niupepa Māori, URL http://www.nzdl.org/gsdlmod?gg=text\&e=d-00000-00---off-0niupepa--00-0----010-0---0---0direct-10---4-------0-1|--11-en-50---20-about---00-0-1-00-0--4----0-011-10-0utfZz-8-00\&a=d\&c=niupepa\&cl=CL1.28\&d=36acommentary, accessed 28 January 2015.

Curnow, et. al., He Pitopito Korero No Te Perehi Maori: Readings from the Maori Language Press, Auckland, 2006.

Daley, Caroline, 'Modernity, Consumption and Leisure', in Giselle Byrnes, ed, The New Oxford History of New Zealand (Melbourne: Oxford University Press, 2009).

Finkelstein David and Alistair McCleery (eds.), The Book History Reader, London, 2006.

Gilmore, William J., Reading Becomes a Necessity of Life: Material and Cultural Life in Rural New England, 1780-1835 (Knoxville: University of Tennessee Press, 1989).

Griffith Penny, Ross Harvey Ross, and Keith Maslen (Eds.) Book \& Print in New Zealand (Wellington: Victoria University Press, 1997). 
Griffith Penny and Phil Parkinson (compilers), Books in Māori 1815-1900/ Ngā Tānga Reo Māori: An Annotated Bibliography/ Ngā Kohikohinga Me Ōna Whakamārama (Auckland: Reed Publishing, 2004).

Haami, Bradford, Pūtea Whakairo: Māori and the Written Word (Wellington: Huia Publishers, 2004).

Haami, Bradford, 'Tā te Āo Māori', in Danny Keenan (ed.) Huia Histories of Māori (Wellington: Huia Publishers, 2012).

Bradford Haami, 'Maaka, Golan Haberfield', Te Ara - the Encyclopedia of New Zealand; $\quad$ http://www.teara.govt.nz/en/biographies/4m1/maaka-golanhaberfield; accessed 11 February 2015.

Harding, Coupland, 'Relics of the First New Zealand Press', in TNZI vol. 32, 1899, pp. 401-404.

Harvey, Ross, 'David Burn and the Māori Messenger', in Script \& Print, vol. 37, issue 2, August 2013, pp. 69-87.

Head Lyndsay and Buddy Mikaere, 'Was $19^{\text {th }}$ century Maori Society Literate?', Archifacts, Conference Papers, Vol.2, 1988, pp.17-20.

Hessell, Nikki, 'Romantic Literature and Indigenous Languages: Reading Felicia Hemans in te reo Māori' in Europan Romantic Review, Vol. 20, Issue 2, 2009, pp.261-270.

Hofmeyr, Isabel, The Portable Bunyan: A Transnational History of The Pilgrim's Progress, Princeton, 2003.

Illich Ivan, and Barry Sanders, The Alphabetisation of the Popular Mind, London, 1988.

Jenkins, Kuni, Becoming Literate, Becoming English: A Research into the Beginnings of English Literacy within Maori Society. Monograph, no. 14. (Auckland: Research Unit for Maori Education, University of Auckland, 1993).

Kaa Wiremu, and Te Ohorere, Ngā Kōrero a Reweti Kohere Mā (Wellington: Victoria University Press, 1994).

Keane, Basil, 'Te rāngai mahi - Māori in the workforce - The rural workforce', Te Ara - the Encyclopedia of New Zealand; URL www.TeAra.govt.nz/en/te-rangaimahi-maori-in-the-workforce/page-3; accessed 26 February 2015.

Kohere, Reweti, The Autobiography of a Maori (Wellington: Reed, 1951).

Lineham, Peter, 'To Make a People of the Book: CMS Missionaries and the Maori Bible', in Orbert Glen (ed.), Mission and Moko: The Church Missionary Society in New Zealand 1814-1882, Christchurch, 1992, pp. 152-169.

Lineham, Peter, 'Tampering with the Sacred Text: The Second Edition of the Māori Bible' in A Book in the Hand (Wellington: Auckland University Press, 2000). 
Lyons, Martin, 'New Readers in the $19^{\text {th }}$ Century: Women, Children, Workers', in Guglielmo Cavallo and Roger Chartier (eds.), A History of Reading in the West, (Amherst: University of Massachusetts Press, 2003), pp.313-344.

McKenzie, D. F., Oral Culture, Literacy \& Print in early New Zealand: the Treaty of Waitangi, Wellington, 1985.

McKenzie, D. F., Bibliography and the sociology of texts, London, 1986.

McRae, Jane, 'Maori Literature: A Survey', in Terry Sturm (ed.), The Oxford History of New Zealand Literature in English, Auckland, 1991, pp. 1-24.

McRae, Jane, 'From Māori Oral Traditions to Print', in Penny Griffith, Ross Harvey and Keith Maslen (eds.), Book and Print in New Zealand, Wellington, 1997, pp. 17-39.

McRae, Jane, 'Maori Oral Tradition meets the Book', in Penny Griffith, Peter Hughes and Alan Loney (eds.), A Book in the Hand, Auckland, 2000, p.1, pp. 1-16.

McRae, Jane, 'E Manu, Tena Koe!' 'O Bird, greetings to you': The Oral Tradition in Newspaper Writing', in Jenifer Curnow, Ngapare Hopa and Jane McRae (eds.), Rere Atu, Taku Manu!: Discovering History, Languae and Politics in the MaoriLanguage Newspapers, Auckland, 2002, pp. 42-59.

McRae, Jane, 'Maori Oral Culture and Literature', in Eugene Benson and L. W. Conolly (eds.), Routledge Encyclopedia of Post-Colonial Literatures in English, Second Edition, London, 2005, n.p., available from URL: http://gateway.proquest.com/openurl?ctx ver=Z39.882003\&xri:pqil:res ver=0.2\&res id=xri:lion\&rft id=xri:lion:ft:ref:R04296945:0

Matsuda, Matt K, 'Of Queens and Kinship: Policies and Legacies in the Colonial Pacific', in Jason Coy et al (eds), Kinship, Community, and Self: Essays in Honor of David Warren Sabean (Oxford: Berghahn Books, 2015), pp.73-84.

Meredith Paul and Alice Te Punga Somerville, 'Kia Rongo Mai Koutou ki Taku Whakaaro': Maori Voices in the Alexander Turnbull Library', Turnbull Library Record, Vol.43, 2010/2011, pp.96-105.

Ngata, Apirana, 'The Maori and Printed Matter', in R. A. McKay, History of printing in New Zealand 1830-1940 (Wellington: Wellington Club of Printing House Craftsmen, 1940), pp.48-49.

Ngata, Apirana, Some aspects of Maori culture : an address delivered by The Hon. Sir Apirana Ngata, before the Maori community of Wellington and the Polynesian Society in Ngati-Poneke Hall, June 10,1947, Poneke, 1947.

Ngata, H. M., English-Maori Dictionary (Wellington: Learning Media, 1993). 
O'Brien, Patty, "Think of Me as a Woman": Queen Pomare of Tahiti and AngloFrench Imperial Contest in the 1840s Pacific', Gender \& History, Vol.18, No.1, April 2006, pp. 108-129.

Orbell, Margaret, He Reta Ki Te Maunga, Letters to the Mountain: Māori Letters to the Editor, 1898-1905 (Auckland: Reed Books, 2002).

Parr, C. J., 'A Missionary Library: Printed Attempts to Instruct the Māori', in JPS, Vol.4, no.70, 1961, pp. 429-450.

Parr, C. J., 'Maori Literacy 1843-1867', in JPS vol. 72 no.3, Sept 1963, pp. 211-234.

Paterson, Lachy, Colonial Discourses: Niupepa Māori 1855-1863 (Dunedin: Otago University Press, 2006).

Paterson, Lachy, 'Print Culture and the Collective Māori Consciousness', in JNZL, Vol. 28, issue 2, Nov. 2010, pp. 105-117.

Paterson, Lachy, 'The Kohimārama Conference of 1860: A Contextual Reading', Journal of New Zealand Studies, No.12, 2001, pp.29-46.

Paterson, Lachy, 'Visual identity in Niupepa Māori nameplates and Title-pages: From Traditional to Aspirational', in Script \& Print, Vol. 38, no. 2, 2014, pp-67-79.

Reid, Graeme, 'Swainson, William', from the Dictionary of New Zealand Biography: Te Ara - the Encyclopedia of New Zealand, URL:

http://www.teara.govt.nz/en/biographies/1s29/swainson-william, accessed 18 March 2015.

Rogers, Shef, 'Crusoe among the Māori: translation and Colonial Acculturation in Victorian New Zealand', in Book History, Vol 1, 1998, pp. 182-195.

Rogers, Pat, ed., Defoe: The Critical Heritage (London: Routledge \& Keegan Paul).

Steel, Frances, 'Uncharted Waters? Cultures of Sea Transport and Mobility in New Zealand Colonial History', Journal of New Zealand Studies, No. 12, 2011, pp.137-154.

Stenhouse, John, and G. A. Wood, Christianity, Modernity and Culture: New Perspectives on New Zealand History (Adelaide: ATF Press, 2005).

Thornton, Agathe, Maori Oral Literature: As Seen by a Classicist (Wellington: Huia, 1999).

Tohunga, 'Our Māori Bible', in The New Zealand Railways Magazine, Vol.12, Issue.2, 1 May 1937, n.p.

Traue, J. E., 'Reading as a 'Necessity of Life' on the Tuapeka goldfields in Nineteenth-century New Zealand', in Library History, Vol.23, 2007, pp.41-48.

Traue, J. E., 'The Public Library Explosion in Colonial New Zealand', Libraries \& the Cultural Record, Vol.42, No.2, 2007, pp.151-164. 
Treagus, Mandy, 'From Whakarewarewa to Oxford: Makereti Papakura and the Politics of Indigenous Self-Representation', Australian Humanities Review, Vol. 52, May 2012, http://www.australianhumanitiesreview.org/archive/Issue-May2012/treagus.html

Trollope, Anthony, New Zealand: Being a Portion of the Work Entitled 'Australia and New Zealand," by the Same Author (London: Chapman and Hall, 1874).

Valle, Paola Della, From Silence to Voice: The Rise of Māori Literature (Auckland: Oratia media Ltd., 2010).

Waitangi Tribunal, 'Mahi Pukapuka: the pursuit of literacy', in He Whakaputanga me te Tiriti: The Declaration and the Treaty, The Report on Stage 1 of the Te Paparaki o te Rahi Inquiry, s.5.5. WAI 1040.

Walker, Rangunui, 'Māori studies - ngā tari Māori - Pioneers of Māori studies', Te Ara - the Encyclopedia of New Zealand, updated 19-Nov-14, URL: http://www.TeAra.govt.nz/en/maori-studies-nga-tari-maori/page-1.

Wevers, Lydia, Country of Writing: Travel Writing and New Zealand 1809-1900 (Auckland: AUP, 2002).

Wevers, Lydia, Reading on the Farm: Victorian Fiction and the Colonial World (Wellington: Victoria University Press, 2010).

Wevers, Lydia, 'Fiction - Romance, Māori and pioneer fiction, 1880s to 1910s', Te Ara - the Encyclopedia of New Zealand, updated 14 October 2014. URL: http://www.TeAra.govt.nz/en/fiction/page-2.

Williams, H. W., A Bibliography of Printed Maori to 1900, Wellington, 1924. Available at http://nzetc.victoria.ac.nz//tm/scholarly/tei-WilBibl.html

Williams, H. W., Dictionary of the Maori Language, $7^{\text {th }}$ ed. (Wellington: Legislation Direct, 1971).

Wittman, Reinhard, 'Was There a Reading Revolution at the end of the Eighteenth Century?' in Guglielmo Cavallo and Roger Chartier (eds.), A History of Reading in the West, (Amherst: University of Massachusetts Press, 2003), pp. 284-312. 